\title{
Abraham - a Canaanite? \\ Tracing the Beginnings of the Literary Tradition of Abraham
}

\author{
JANUSZ LEMAŃSKI \\ University of Szczecin \\ lemanski@koszalin.opoka.org.pl \\ ORCID: 0000-0002-1512-997X
}

\begin{abstract}
The objective of the article is to present the current state of discussion on the first literary version of the series about Abraham and its sources or roots. The current state of research suggests that the starting point of the literary version of the narrative about this patriarch may have been a kind of tradition associated with the local shrine in Mamre, near Hebron. The other theory describes the idea of the promise of a descendant in return for the extraordinary and extended hospitality towards God. More importantly, this tradition may have been connected with Abraham from the very beginning, but it does not necessarily have to have been. The first version of a longer narrative about Abraham was the cycle of Abraham - Lot - Sodom (Gen 18*-19*). An introduction to the cycle (Gen 13:5-13) was written, already including the content of the two chapters mentioned above. According to the original version of the cycle, Abraham is not yet closely related to Lot, but he is an autochthonous character. Obviously, the goal of the series remains the ethnogenesis of the inhabitants of Judah in relation to the neighbouring peoples (the Moabites and Ammonites). Moreover, the latter clearly form a negative contrast here - both ethnically and civilisationally. This version of the narrative can be dated back to the end of the 7th century before Christ. The subsequent extensions or enlargements were initially associated with the combining of the characters of Abraham and Jacob. Such a combination could have been achieved, amongst others, by identifying the descendant promised to Abraham with Isaac. The priestly tradition internationalised Abraham even more and thus made him a pilgrim who had come from Ur of the Chaldeans.
\end{abstract}

KEYwORDs: Abraham - Lot, shrine of Mamre, beginning of the tradition, descendant

T he Prophet Ezekiel addressing Jerusalem, said: “... Your ancestry and birth were in the land of the Canaanites; your father was an Amorite and your mother a Hittite." (Ezek 16:3). The wording "land of the Canaanites" instead of the standard "land of Canaan" allows for highlighting the personal character of the statement and the pagan origins of Jerusalem. It was also meant to be a distinct departure from the founding traditions of Judah/Israel (Abraham, exodus). ${ }^{1}$

1 On this subject, cf: W. Pikor Rola ziemi w przymierzu Boga z Izraelem Studium historyczno-teologiczne Ksiegi Ezechiela (Lublin: Wydawnictwo KUL 2013) 182. English version of The Land of Israel in the Book of Ezekiel (LHBOTS 667; London: Bloomsbury Clark 2018). 
The biblical authors often join these three nations together, additionally also with the original Canaanite inhabitants of Jerusalem, the Jebusites. (Gen 10:15-16; Judg 19:11-20; 2 Sam 5:6). The prophet himself intends to imply thereby that Jerusalem has pagan customs 'in its blood,' in order to add weight to the accusation against the contemporary inhabitants of Jerusalem. However, it is only a purely rhetorical reference to the Canaanite origins of pre-Israel Jerusalem, as opposed to a statement pertaining to the ethnic roots of its contemporary inhabitants. Nevertheless, the thesis whereby the birthplace of Israel was in Canaan, and it did not arrive in this land from any region other than the Levant (contradictory to the biblical traditions about the patriarchs and the exodus), is currently one of the most popular ways of explaining the historical origins of Israel and is largely borne out by archaeological discoveries. ${ }^{2}$

In the Book of Ezekiel, one also finds the first, and thus chronologically the oldest (apart from the Pentateuch), mention of Abraham (cf. Ezek 33:24). Importantly, this mention is devoid of any religious connotations. It is a reference to the patriarch, who developed the land, as the forebear of the people of Judea. The inhabitants who were not deported to Babylonia in $597 \mathrm{BC}$ cited his figure to support their stance that the land was rightfully theirs. However, this way of reasoning among the people of Judea is subject to religious correction (Ezek 33:25-25) and judgement (Ezek 33:27-29). This, however, does not change the fact that the reference to the patriarch relates to some already well-established and well-known tradition in Judea, in which Abraham appears in the role of a figure allowing the people of Judea to assert their identity. Thus, the Abrahamic tradition was not entirely developed during the Babylonian exile and later, but it existed in some form prior to the exile. This prompts the question as to what the pre-exile tradition contained. ${ }^{3}$ What follows from the laconic statement is the emphasis placed on the fact that there was "one" Abraham (as later stated in Isaiah 51:2). The patriarch is perceived as the owner of the land; however, this ownership does not come from any God's promise. Consequently, it cannot be proved on this basis that the prophet knew an earlier version of Gen $15 .{ }^{4}$ Finally, the most important element of this statement pertains to the belief that Abraham appears to be an indigenous individual to the people of Judea, in contrast to someone who had come 'from outside,' as the later elements of the Abrahamic cycle suggest (cf. Gen $11: 31 ; 12: 1-5 ; 15: 7){ }^{5}$

2 L.L. Grabbe, Ancient Israel. What Do We Know And How Do We Know It New York (London: Continuum 2007; reprint 2009) 118-122; C. Frevel, Geschichte Israels, 2 ed. (Stuttgart: Kohlhammer 2018) 67-96.

3 A. Mühling, »Blickt auf Abraham, euren Vater «. Abraham als Identifikationsfigur des Judentums in der Zeit des Exils und des Zweiten Tempels (Göttingen: Vandenhoeck \& Ruprecht 2011) 84-90.

4 Cf. the argumentation in Mühling, Blickt, 88.

5 Mühling, Blickt, 89. 
We wish to have a closer look at the latter issue in this article, trying to reach the oldest literary layer of the Abrahamic cycle. It is our belief that this will allow for determining whether the content and message contained therein preserved this indigenous portrayal of the patriarch.

\section{Canaan and the Canaanites}

First, the terms 'Canaan' and 'Canaanites' need to be clarified. Extra-biblical texts use the words 'Canaan' and 'Canaanite' mainly as a term of territorial description. In Egyptian, Mesopotamian and Ugaritic sources it usually refers to the areas of the present-day Israel and Palestine, as well as Lebanon (former Phoenicia). ${ }^{6}$ The latter term covers various ethnic groups in those areas. Each of the groups could have had its own ethnic name, and the generalizing term 'Canaanite' may have been used only by outsiders looking at Canaan's from outside. The people of Canaan had predominantly Semitic roots, but they did not constitute a single nation or country. The political and social system which developed there is currently termed a city-state. Virtually until their decline (mainly in the thirteenth and partly in the twelfth century BC) they were subjugated by Egypt, as evidenced by the correspondence with Tell el-Amarna. ${ }^{7}$ There one finds, among others, the so-called 'passport,' i.e., a letter from the ruler of Mitanni to the 'kings of Canaan' (a-an LUGAL.MEŠ ša KUR Ki$n a-a-a h[h i])$, in which he asks for a passage through their territories for his messenger (EA 30). ${ }^{8}$ In legal texts in turn the term 'man from Canaan' was a name for a debtor (LÚ URU $K i-i n-a-n i_{7}{ }^{K I}$ ). ${ }^{9}$

In the Bible the term also refers generally to the territory in which part of the Promised Land and its original inhabitants are situated. Therefore, it occurs most often as a generic concept (Gen 12:6; Deut 11:30; 21:1; Josh 3:10; 5:1; 17:16.18; Judg 1:9-17.27-33). Often, however, the Canaanites are also mentioned as one of the peoples who inhabited Canaan before the Israelites (Cf. Gen 15:19-21); Exod 3:8; 23:23; 34:11; Deut 20:17; Josh 9:1; Judg 3:5). In this case the term acquired an ethnic significance, although this meaning bears little correspondence to the historical reality. The biblical authors then trace

6 A.E. Killebrew, Biblical Peoples and Ethnicity. An Archaeological Study of Egyptians, Canaanites, Philistines, and Early Israel 1300-1000 B.C.E. (ABS 9; Atlanta, GA: Society of Biblical Literature 2005) 94.

7 A.F. Rainey, The El-Amarna Correspondence (HdO 110/1-2; Leiden - Boston: Brill 2015) I-II.

8 Rainey, The El-Amarna I, 324-325.

9 A.F. Rainey, "Who Is a Canaanite? A Review of the Textual Evidence," BASOR 304 (1996) 3; N. Na'aman, "Four Notes on the Size of Late Bronze Canaan," BASOR 313 (1999) 32. 
the Canaanites back to Ham and link them to the Egyptians, the Cushites, and Put (Gen 10:6), even though the vast majority of the Canaanites were Semites. Thus, this classification, as one can easily see, is emotional rather than factual, as from the outset the biblical authors (cf. Gen 9:20-27) load this term with negative connotations, ${ }^{10}$ bringing to the foreground the cultural, religious and moral differences between the Canaanites and the Israelites. However, as Lester L. Grabbe writes, ${ }^{11}$ the use of the term " "Canaanite' as a contrast to [the word] 'Israelite' is nonsense - Israelites were as much Canaanite as anyone else."

Bearing these observations in mind, one should note that when we refer to Abraham as a Canaanite, we mean not so much the negative biblical image of the Canaanites as the possible historical roots of this biblical figure.

\section{Israel from Canaan}

The biblical authors - as has been already noted - stress the origins of Israel's ancestors as distinct from the indigenous people of Canaan. First, the patriarchs are shown to be related to the Arameans through family ties and to have roots in Mesopotamia, from where they were said to have come to Canaan and live there as settlers. Then, still as one large family, those ancestors migrated to Egypt where they became a great nation. They returned therefrom and conquered Canaan. According to historians, however, everything proceeded in a different way. Presently, many researchers believe that the ancestors of the Israelites were, in fact, also Canaanites. This belief stems not only from the fact that many elements of Israel's culture and religion have their roots in Canaan. ${ }^{12}$ These facts could be easily explained by close contacts with Canaanite culture. For a certain period of time, some archaeologists even tried to indicate certain cultural peculiarities characteristic of the people inhabiting the central mountain belt of Canaan in the Iron Age I. Those communities, considered by them to be the ancestors of Israel, were characterised by erecting distinctive houses with roofs mounted on pillars. However, the researchers' attention was primarily drawn to the so-called four-room houses..$^{13}$ Attempts were made to prove that they were typical of the areas asso-

\footnotetext{
N. Na'aman, "Memories of Canaan in the Old Testament," UF 47 (2016) 129-146.

Grabbe, Ancient Israel, 51.

Na'aman, "Memories," 129-131.

V. Fritz, "Dom [Home]," V. Fritz, Archeologia biblijna (Mały Słownik; Warszawa: Verbinum 1995) 47-49, esp. 48. Discussing these topics, it is worth giving particular attention to an important monograph by Israel Finkelstein (The Archeology of the Israelite Settlement [Jerusalem: Israel Exploration Society 1988]).
} 
ciated with Israel in the Bible. ${ }^{14}$ These architectural elements, along with ceramic ones, were considered to be characteristic for the first Israelites. However, further research demonstrated that this type of construction is not typical only for these communities. ${ }^{15}$ It was also shown that the construction of four-room houses resulted mostly from conducting an agricultural and/or pastoral way of life and cannot have been any distinctive feature of putative proto-Israelites. In fact, the already well-known map of the re-settlement of Canaan after the fall of the Canaanite city-states in the thirteenth and twelfth centuries before Christ, ${ }^{16}$ is conducive to the creation of new theories about the nomadic and pastoral roots of Israel. On the other hand, the biblical authors did not display too much interest in the life of nomads. ${ }^{17}$ Their depiction in the Bible is quite impassive..$^{18}$ There is no trace of any nomadic ideal or tradition showing Israelites to have come from such groups. Consequently, an expert on this subject, Kenton Sparks, ${ }^{19}$ thinks that it is unwise to associate the Israelites with any particular group (e.g., Kenites, Midianites). In his opinion, the experiences related to nomadism, as they were recorded in the Bible, come from various locations, concern various forms of nomadic life and, to some extent, originate from Canaanite nomadism as well. The latter is highlighted by the above-quoted Israel Finkelstein who points to the migration processes taking place in the Bronze and Iron Age between the mountainous centre of Canaan and its lowland regions (the so-called fluctuations). This process was accompanied by the variability of the lifestyle, which was sometimes based on land cultivation and, at other times, on pastoralism. According to this researcher, Israel as a socio-political entity originated from one of these fluctuations. Although Finkelstein assumes that nomadic pastoral groups from outside came to Canaan in the Bronze Age, they were already well assimilated with the Canaanites and their culture when Israel was being formed. Therefore, the fundamental problem in identifying the ancestors of Israel is the lack of a way to distinguish Canaanites from potential proto-Israelites.

For the above reasons, a new term "mixed multitude" has been recently applied (cf. Exod 12:38). Despite its imprecision, it successfully replaces - with

14 A. Faust - S. Bunimovitz, "The Four Room Hause: Emboding Iron Age Israelite Society," Near Eastern Archeology 66 ( 2003) 22-61; A. Faust, Israel's Ethnogenesis. Settlement, Interaction, Expansion and Resistance (London - Oakville, CT: Equinox 2006) 75-78.

15 E. Bloch-Smith, "Israelite Ethnicity in Iron I: Archeology Preserves What Is Remembered and What Is Forgotten in Israel's History," JBL 122 (2003) 401-425, esp. 407-408.

16 E. Bloch-Smith - B.A. Nakhai, "A Landscape Comes to Life: The Iron Age I," NEA 62 (1999) 62-127.

17 K.L. Sparks, "Israel and the Nomads of Ancient Palestine," Community Identity in Judean Historiography. Biblical and Comparative Perspective (eds. G.N. Knoppers - K.A. Riston) (Winona Lake, IN: Eisenbrauns 2009) 9-26, https://www.academia.edu/1059818 [access: 4.09.2020].

18 Sparks, "Israel," 25-26.

19 Sparks, "Israel," 26. 
increasing frequency - the descriptive statement according to which the origins of Israel should be treated "as a reflection of a heterogeneous, multi-faceted and complex process of formation and crystallisation." ${ }^{20}$ Ann E. Killebrew ${ }^{21}-$ like the above-mentioned Israel Finkelstein and many other researchers, believes that at the end of the Bronze Age, the central, mountainous range of Canaan was mainly inhabited by the indigenous population of Canaan. However, in her opinion, other ethnic groups also began to come to Canaan over time, such as former Egyptian slaves, migrating groups of the rural population, shepherds, the "Apiru" operating outside law, representatives of the nomadic Shasu tribes and also more organized groups of Midianites, Kenites and Amalekites. The theory of such an ethnic and cultural mix, the product of which was later Israel, undoubtedly makes it easier to combine the existing models explaining the origins of Israel in Canaan, such as the model of conquest, peaceful coexistence and/or infiltration, or the aforementioned assumptions about Israel's nomadic-pastoral roots. However, it does not explain in a satisfactory way how all these diverse elements became unified with each other.

Where should the figure of Abraham be placed in the blurred picture of the origins of Israel? At the outset, it is worth noting that, contrary to popular beliefs, the biblical portrait of this patriarch does not reflect the nomadic pastoral tradition at all. Such connotations may only be possessed by the figure of the patriarch Jacob. However, in the case of Abraham, basically only mentions of living in a tent could be a reference to this kind of lifestyle.

\section{Abraham of Hebron}

It is not difficult to notice, even from a cursory reading of the Abraham cycle that one of the most important places associated with this patriarch is Hebron. In the second millennium before Christ, there were essentially three major political centres in the areas of the future kingdoms of Israel and Judah, Hebron was one of them, along with Shechem and Jerusalem. The city-state of Jerusalem held power over a fairly small territory in its immediate vicinity during the Mid-Bronze Age

20 A.E. Killebrew, "The Emergence of Ancient Israel: The Social Boundaries of a 'Mixed Multitude' in Canaan," "I Will Speak the Riddles of Ancient Times." Archaeological and Historical Studies in Honor of Amihai Mazar on the Occasion of His Sixtieth Birthday (eds. A.M. Maeir-P. de Miroschedji) (Winona Lake, IN: Eisenbrauns 2006) 566: "as reflecting a non-homogeneous multifaceted, and complex process of Israelite formation and crystallization."

21 Killebrew, "The Emergence," 571 . The use of this term is also accepted by William G. Dever (Who Where the Early Israelites and Where Did They Come From? [Grand Rapids, MI: Eerdmans 2003] 181-182) (his version is "motley crew"). 
and Late Bronze Age. ${ }^{22}$ It ruled this area perhaps by resorting to the help from "Apiru" groups roaming this sparsely populated territory. Hebron seemed to have been a much more important city at the same time, with links to the main clans which later on co-created the tribe of Judah. ${ }^{23}$ The remains of Hebron from the Middle Bronze Age (Tel er-Rumeideh) bear evidence to the fact that the city was surrounded by a circle of strong walls and covered an area of 23,000-30,000 square meters. ${ }^{24}$ A cuneiform text dating back to the 18th century BC was also discovered here. ${ }^{25}$ It refers to offerings of goats sacrificed whole or partially in some sanctuary located here or nearby. On this occasion, a king was mentioned several times. This may suggest that the aforementioned tablet was part of royal archives. Therefore, Hebron was a royal city at the turn of the 17th and 16th centuries before Christ. During the Late Bronze Age, however, Hebron lost its importance. After its decline Khirbet Rabûda city identified as the biblical Debir, rose to prominence in this region. ${ }^{26}$ Both Hebron and later on Debir must have controlled Beersheba and Arad to the east, and then Tel Maros and Tel Malhata to the south, and Beth-Zur to the north. The economy based on crop cultivation and breeding small flocks of sheep and goats was dominant in both Hebron and Debir. ${ }^{27}$

Oded Lipschits ${ }^{28}$ puts forward a thesis whereby the Abrahamic tradition had only a local scope for a long time, because it did not raise interest among the elite ruling Jerusalem, later conquered by David. Only after the fall of this city as a result of the second Babylonian invasion (587/586 BC), when the Jerusalem elites lost their monopoly on worship, preferred traditions and historiography, in the Abrahamic tradition become well-known to a wider group of inhabitants of the former Kingdom of Judah (cf. Ezek 33:24). As an argument, Lipschits cites the fact that the figure of Abraham is not mentioned by any of the monarchical period prophets or by Deuteronomist historiographers. The reason here, however, could also be the centralist aspirations of the Deuteronomist school, which

22 N. Na'aman, "Canaanite Jerusalem and Its Central Hill Country Neighbors in the Second Millenium B.C.E.," UF 24 (1992) 275-291; already A. Alt, "Die Landname der Israeliten in Palästina," A. Alt, Kleine Schriften zur Geschichte des Volkes Israel (München: Beck 1953) I, 89-125, esp. 107-108.

23 Na'aman, "Canaanite Jerusalem," 280-288.

24 O. Lipschits, "Abraham zwischen Mamre und Jerusalem," The Politics of the Ancestors (eds. M.G. Brett - J. Wöhrle) (FAT 124; Tübingen: Mohr Siebeck 2018) 187-209, esp. 189.

25 M. Anbar-N. Na'aman, "An Account Tablet of Sheep from Ancient Hebron," TA 13-14 (1986-1987) 3-12, esp. 3-5, https://www.academia.edu/12932470 [access: 3.10.2020]. Photographs of the text can also be found in: A. Ofer, "Hebron," The Encyclopedia of Archaeological Excavations in the Holy Land (ed. E. Stern) (New York et al.: Simon \& Schuster 1993) II 606-609, photo. 608.

26 M. Kochavi, "Khirbet Rabåd = Debir," TA 1 (1974) 2-33; A. Ofer, "All the Hill Country of Judah: From a Settlement Fringe to a Prosperous Monarchy," From Nomadism to Monarchy. Archaeological and Historical Aspects of Early Israel (eds. I. Finkelstein - N. Na'aman) (Jerusalem: Israel Exploration Society 1994) 38-39, 96, 110.

27 Lipschits, "Abraham," 190.

28 Lipschits, "Abraham," 187-209. 
ignored any other centres of cult outside Jerusalem, considering them unorthodox. When talking about the beginnings of the tradition related to Abraham, one should undoubtedly also think about the sanctuary under the Mamre oak (s).

\section{A Diachronic Approach to the Abraham Cycle}

Our goal is to reach the oldest layer of the literary tradition of Abraham. Firstly, it requires that younger literary layers be isolated from the oldest ones and then it requires the determination of which part of the presently known cycle constituted its original core.

\subsection{Priestly Texts $(P)$ in the Abraham Cycle}

Researchers, with only minor differences, agree on assigning the following passages in the cycle to $\mathrm{P}:{ }^{29}$ Gen $11: 27-28 \mathrm{a} .29-32 ; 12.4 \mathrm{~b} .5 ; 13,6,11,12 \mathrm{~b} ; 16$, $3,15-16 ; 17 ; 19.29 ; 21.1 b-5 ; 23 ; 25.7-10$. Of course, depending on the author, sometimes there appear opinions diverging in detail. The reason for these differences is that some texts, classified as P contain later extensions, or have features not entirely typical of P. A good example is the "typically priestly" text of Gen 17, which is today treated as more complex in the literary aspect than it might seem at first glance. ${ }^{30}$ It is similar in the case of Gen 23. This

29 A. de Pury, “Genèse 12-36," Introduction à l'Ancien Testament, 2 ed. (ed. T. Römer - J.-D. Macchi C. Nihan) (MdB 49; Genève: Labor et Fides 2009) 224-225; O. Lipschits - T. Römer - H. Gonzalez, "The Pre-Priestly Abraham Narratives from Monarchic to Persian Times," Sem 59 (2017) 263. Cf. a slightly different assignment of some poems in T. Dozeman, The Pentateuch. Introducing the Torah (Minneapolis, MN: Fortress 2017) 244-246 ( $\mathrm{P}=$ Gen 11:27-32; 12:4b-5; 13:6.11b; $16: 1-16 ; 17 ; 19: 29 ; 21: 1.3-5 ; 22: 20-24 ; 23 ; 25: 1-6.7-11.12-18)$.

30 J. Lemański, Księga Rodzaju. Rozdziały 11,27-36,43. Wstęp - przekład z oryginatu - komentarz (NKB.ST 1/2; Częstochowa: Edycja Świętego Pawła 2014) 283-286; then also J. Wöhrle, "The Integrative Function of the Law of Circumcision," The Foreigner and the Law. Perspectives from the Hebrew Bible and the Ancient Near East (eds. R. Achenbach - R. Albertz - J. Wöhrle) (BZABR 16; Wiesbaden: Harrassowitz 2011) 71-87; M. Köckert, “Gottes 'Bund' mit Abraham und die 'Erwählung Israels in Genesis 17," Covenant and Election in Exilic and Post-Exilic Judaism (ed. N. MacDonald) (Studies of the Sofia Kovalevskaja Research Group on Early Jewish Monotheism 5; FAT 2/9; Tübingen: Mohr Siebeck 2015) 1-28; T. Römer, "Beschneidung in der Hebräischen Bibel und ihre literarische Begründung in Genesis 17," Dem Körper eingeschieben. Verkörperung zwischen Leiberleben und kulturellem Sinn. Studien zur Interdisziplinären Anthropologie (eds. M. Jung - M. Bauks - A. Ackermann) (Studien zur Interdisziplinären Anthropologie; Wiesbaden: Springer 2016) 227-241. 
text is classified by some as a later stage in editing the cycle and by others as belonging to Grundschrift-P. ${ }^{31}$

Despite such problems, it can be stated with a great deal of certainty that the $\mathrm{P}$ version, in the case of the Abraham cycle - unlike in the Jacob cycle - appears to be consistent and has few "gaps" (Ger. Leerstele) disturbing the continuity and logic of narration. Thanks to this, it is possible to reconstruct, with relative coherence, the priestly story of Abraham and Sarah within Gen 11:27-25:11. The problem, however, lies in whether this version was developed independently and only later on was incorporated into another, older version of the text about patriarch. It could also be surmised that from the very beginning it was a revision and supplement to the non-P version. Such suggestion may be derived from the priestly interlinear gloss of Gen 19:29. Its author probably had such an older version of the story before his eyes and decided that in this particular case adding a short supplementary comment should be enough. ${ }^{32}$ Of course, it should be borne in mind that this gloss could have been added when the $\mathrm{P}$ version was combined with a non-P one and that it has an editorial character.

\subsection{Non-P Texts Posing Problems for Unequivocal Classification}

These texts include, first of all, two pericopes from Gen 14-15. The pericope of Gen 14 has always caused the most trouble for researchers. Abraham, throughout the cycle, is depicted as an aged man, journeying with God and having a peaceful attitude to the circle of people around him. In Gen 14 he suddenly becomes a warrior, commanding a large force of servants and emerges victorious in a great "world war." 33 In this way, however, the author of this pericope introduced the patriarch to the stage of great history. The whole story, therefore, may be one of the last voices in the reinterpretation of the personage of Abraham. Today, this text is no longer seen as archaic (like older comments and elaborations) but as a relatively late one. It was even associated with the atmosphere of the Maccabean times and was set therein. ${ }^{34}$ However, most researchers point to

31 See the discussion in: J. Wöhrle, Fremdlinge im eigenen Land. Zur Entsteheung und Intention der priesterlichen Passagen der Vätergeschichte (FRLANT 246; Göttingen: Vandenhoeck \& Ruprecht 2012) 58-63; idem, “'Gebt mir einen Grabbesitz bei euch'. Zur Entstehung und Intention der Erzählung von Abrahams Grabkauf in Genesis 23," Eigensinn und Entstehung der Hebräischen Bibel (eds. J.J. Krause - W. Oswald - K. Weingart) (FAT 136; Tübingen: Mohr Siebeck 2020) 63-76; Lemański, Księga Rodzaju, 520-522.

32 Dozeman, The Penateuch, 247; Lipschits - Römer - Gonzalez, "The Pre-Priestly,” 263.

33 For a discussion cf. Lemański, Księga Rodzaju, 162-171.

34 A view held by Jan A. Soggin ("Abraham and the Eastern Kings: on Genesis 14," Solving Riddles and Untying Knots. Biblical Epigraphic, and Semitic Studies in Honor of Jonas C. Greenfield [eds. Z. Zevit - S. Gitin - M. Sokoloff] [Winona Lake, IN: Eisenbrauns 1995] 283-291). 
an unspecified, late Persian period. On the one hand, Gen 14 is a peculiar crypto-text, introducing Jerusalem into the orbit of the biblical narration about Abraham (cf. $2 \mathrm{Chr}$ 3:1 and Gen 22), and on the other hand, this chapter definitely settles the boundaries of the Promised Land (cf. Gen 13-14). ${ }^{35}$ Indeed, after Gen 14, the only topic will be the promised offspring (cf. Gen 15-22).

Gen 15 in its current form already assumes the existence of Gen 14 (cf. verb root mgn in Gen 14:20: miggên; 15:1: māgeenn). ${ }^{36}$ However, this may be a later editorial procedure, so it does not have to mean, that both texts were written at the same time or that the second one was written under the influence of the first. In fact, this pericope had a longer development path and some older version can be recreated from it. ${ }^{37}$ Its extension, along with post-P texts, may have been aimed at introducing exodus tradition elements to the story of Abraham. Yhwh in fact presents himself here (Gen 15:7) as the one who led Abraham out of Ur of the Chaldeans. Therefore, the author of this statement transfers the preamble from Decalogue onto Abraham, making him, as Thomas Römer said, ${ }^{38}$ "exodische Figur." Simultaneously, the same author corrects the classic priestly presentation of events (Gen 11:27-32), in which Terah set out from Ur of the Chaldeans (cf. Gen 11:31-32), and Abraham set out further, towards Canaan, only from Haran. ${ }^{39}$ The new version of Gen 15 also makes Abraham (unlike in Deut 18:15-22: Moses in the role of the prototype of a prophet) the first prophet (similarly to Gen 20:7). ${ }^{40}$

The longest pericope in the Book of Genesis - Gen 24 - is clearly from a later period. Its "baroque" panache and the idea of an "angel" standing watch over the main character, resembles the atmosphere of the Book of Tobit, and thus a style close to a short story from Persian times. This chapter is also set in the late Persian period. ${ }^{41}$

35 B. Ziemer, Abram-Abraham. Kompositionsgeschichtliche Untersuchungen zu Genesis 14, 15 und, 17 (BZAW 350; Berlin - New York: de Gruyter 2005) 92; V. Glissmann, "Genesis 14: A Diaspora Novella?," JSOT 34 (2009) 34-45; A. Wagner, Genesis 14. Its Literary Growth, Its Messages, and Historical Conexts (MA Thesis; Tel Aviv University 2014).

36 For other details, cf. A. Caquot, "L'alliance avec Abram (Genèse 15)," Sem 12 (1962) 51-66.

37 J.C. Gertz, "Abraham, Mose und der Exodus. Beobachtungen zur Redaktionsgeschichte von Genesis 15," Abschied vom Jahwisten. Die Komposition des Hexateuch in der jüngsten Diskussion (eds. J.C. Gertz - K. Schmid - M. Witte) (BZAW 315; Berlin - New York: de Gruyter 2002) 63-81; C. Levin, "Jahwe und Abraham im Dialog: Genesis 15," Gott und Mensch im Dialog. Festschrift für Otto Kaiser zum 80. Geburtstag (ed. M. Witte) (BZAW 345; Berlin - New York: de Gruyter 2004) 237-257; for a discussion of the research and the articles mentioned here, cf. Lemański, Ksiega Rodzaju, 223-227.

38 T. Römer, "Die politische Funktion der vorpriesterlichen Abrahamtexte," The Politics of the Ancestors (eds. M.G. Brett - J. Wöhrle) (FAT 124; Tübingen: Mohr Siebeck 2018) 211-232, esp. 213.

39 Wöhrle, Fremdlinge, 25-30.

40 On this subject, cf. Lemański, Ksiega Rodzaju, 229-231.

41 Lemański, Księa Rodzaju, 543; A. Rofé, "The Admonitions not to Leave the Promised Land in Genesis 24 and 26 and the Authorization in Genesis 46," The Post-Priestly Pentateuch 
Finally, the approach to Gen 20-22 has also changed. Formerly these chapters were attributed to the alleged Elohist. Today, the vast majority of researchers consider them to be post-P..$^{42}$ It is not difficult to notice that there is a strong connection between the pericopes from Gen 21-22 (the offspring threat and the role of a parent, mother and father respectively). Today, the story about the would-be son sacrifice and its replacement with a ram sacrifice is considered to be, without a doubt, post-exile. ${ }^{43}$ As we mentioned, Jerusalem is also brought into the orbit of the Abraham tradition (crypto-text: sacrifice in Moriah, cf. 2 Chr 3:1). ${ }^{44}$ In Gen 20 we find a later parallel to Gen 12:10-20 and possibly also to Gen 26 (the theme of wife introduced as a sister) ${ }^{45}$ What draws attention here is the grammatical peculiarity typical of the later period (Gen 20:10: $\left.m \bar{a} h r_{\bar{a}}{ }^{i} t \bar{a}\right) .{ }^{46}$ In Gen 20:4, Abimelech is presented as a pious "goy," a God-fearing pagan ${ }^{47}$ (cf. the image of pagan sailors in Jonah 1), and Abraham as a prophet (Gen 20:7; cf. Gen 15:1). Consequently, today the entire last part of the Abraham cycle (Gen 20-25) is considered to be a $\mathrm{P} /$ post-P composition. ${ }^{48}$

\subsection{An Older Composition in the Abraham Cycle}

The above presented findings allow us to search for the oldest version in the Abraham cycle in Gen 12-13.16.18-19. However, in the chapters mentioned above, not all passages can be classified as "older" than P. In Gen 18, a clearly later addition is Abraham's dialogue with God on the justice of God's judgments (Gen 18:18-19.22-23) ${ }^{49} \mathrm{We}$ can, therefore, exclude this fragment of the text from

(eds. F. Giuntoli - K. Schmid) (FAT 101; Tübingen: Mohr Siebeck 2015) 177 with an indication of earlier works by this author; cf. also Lipschits - Römer - Gonzalez, "The Pre-Priestly," 265; Römer, "Die politische," 213.

42 Lemański, Księga Rodzaju, 413-416; M. Köckert, "Gen 20-22 als nach-priestliche Erweiterung der Vätergeschichte," The Post-Priestly Pentateuch (eds. F. Giuntoli - K. Schmid) (FAT 101; Tübingen: Mohr Siebeck 2015) 157-176.

43 Köckert, "Gen 20-22," 173-176.

44 The name "Moriah" could also have been chosen because of the sanctuary in Shechem (oaks of Moreh), which later allowed the Samaritans to apply this text to Mount Gerizim. The interpretation of $2 \mathrm{Chr} 3: 1$, as a later correction, was an interpretatio judaica; C. Nihan, "Abraham Traditions and Cult Politics in the Persian Period. Moriyyāh and Šalem in Genesis," The Politics of the Ancestors (eds. M.G. Brett - J. Wöhrle) (FAT 124; Tübingen: Mohr Siebeck 2018) 259-281, esp. 260-272.

45 Römer, "Die politische," 213.

46 E. Blum, Die Komposition der Vätergeschichte (WMANT 57; Neukirchen-Vluyn: Neukirchener Verlag 1984) 414.

47 Blum, Die Komposition, 408-409, n. 13.

48 Römer, "Die politische," 214-215.

49 A view held by Lipschits - Römer - Gonzalez, "The Pre-Priestly," 263-271; however, the question of which poems in this pericope (Genesis 18:17-33) appeared later, and which are part of the earlier narrative, is still debatable; cf. Lemański, Księga Rodzaju, 343-346. 
the older version of the cycle we are looking for. In turn, perhaps some passages from Gen 21:1-7 (the birth of Isaac) should be added to this group of older texts. ${ }^{50}$ However, the affiliation of individual lines in this passage $(\mathrm{P} /$ not-P/post-P) is debatable.

\subsubsection{A Few Leading Opinions}

The problem in the debate on the "original version" of the Abraham cycle is its dating and defining its original theological purpose. So, let us take a look at some of the leading opinions. Let us start with John Van Seters. ${ }^{51}$ This scholar postulated two earlier phases in the literary development of the Abraham cycle. They are thought to have preceded the version created by the Yahwist from the period of exile postulated by him. Among these older stages of formation, Van Seters points to the texts linking Abraham to Egypt (Gen 12:10-20; 16:1-12) and the account of the birth of Isaac (18:1a.10-14; 21:2.6-7). He looks for an introduction to these texts in Gen 12:1,4a.6a.7. The first extension of this original version was in his opinion - the texts linking the patriarch with Abimelech (Gen 20:1-17; 21:25-26.28-31a). This is the second phase of pre-Yahwistic development assigned by him to the Elohist. Both of the pre-Yahwistic versions he postulated (the original and the extended one), as it is easy to guess, date back to the period preceding the Babylonian exile. ${ }^{52}$

Erhard Blum approached the research on the Abraham cycle quite differently. ${ }^{53}$ This researcher, first of all, rejected the classic nomenclature from the previous theory of sources and proposed a completely new approach to the texts from the Book of Genesis. The original literary layer of the Abraham cycle - believes Blum - was Gen 13*54; 18,1-16.20-22a; 19* (the so-called Abraham-Lot-Erzählung). In the dispute between Abraham and Lot's shepherds (13*), this researcher saw the introduction to Gen 18-19. Then Blum points to the parallels with the cycle about Jacob (Gen 13; 28: the promise theme). He called this stage in constructing the cycle Vätergeschichte 1 . The dating of this original mini-cycle underwent certain evolution in the course of his further research. Initially, he believed ${ }^{55}$ that this version of the cycle was written before the Babylonian exile.

50 Such inclusion is postulated by Nadav Na'aman ("The Pre-Priestly Abraham Story as a Unified Exilic Work," SJOT 29/2 [2015] 157-181).

51 J. Van Seters, Abraham in History and Tradition (New Haven, CT - London: Yale University Press 1975) 311, 313; idem, Prologue to History. The Yahwist as Historian in Genesis (Louisville, KY: Westminster John Knox1992) 246-247.

52 Van Seters, Abraham, 171-175, 183-185.

53 Blum, Die Komposition, 273-289, 461-466; idem, “Abraham I,” $R G G$ I, 70-72.

54 The sign * means that it is only a fragment of a given line/pericope.

55 Blum, Die Komposition, 273-297. 
Later, however, he changed his mind ${ }^{56}$ and expressed the opinion that the original version was written during the Babylonian exile, shortly before the appearance of the $\mathrm{P}$ version. The main interests of the authors of this version - according to Blum - concentrated on the subject of the descendant and on the origin of the Israelites, Ammonites, and Moabites. In the second stage, during the period of exile, this version was extended (Vätergeschichte 2) with further promises, the story of Isaac (Gen 26), new episodes related to Abraham (Gen 12:10-20; 21:8ff; 16 [Ishmael]; 22*) and an itinerary marked with the theme of building altars in consecutive stop over locations. With the introduction of the central themes: people, earth and blessing, this composition began to constitute the identity foundations of Israel, necessary after the catastrophe of the fall of statehood and the Babylonian exile. In still later stages, more elements were added, the socalled $D$-Bearbeitung: $12.7 ; 15 ; 16.10 ; 18.17-19.22 \mathrm{~b}-32 ; 20 ; 21.22 \mathrm{ff} ; 22,15-18$; 24; P-Bearbeitung: Gen 17; texts with the motif of El Shaddai; tôlédôt, itineraries, and chronological information. In the last stage, Gen $23^{*}$ (purchase of a field and a grave) and Gen 14 (the matter of the boundaries of the Promised Land) were added. Views similar to the two researchers mentioned above, with an attempt to reconcile them, were expressed much later by, among others, Rainer Albertz. ${ }^{57}$

Inmtraud Fischer, in turn, approaches the observed divergence in the opinions of Van Seters and Blum in a different way. ${ }^{58}$ This researcher points to two separate thematic cycles. One is developed in Gen $12,10-20 ; 16^{*} ; 18,1-15 ; 21,1-7$, and the other one in Gen 13*; 19*. In her opinion, the first one is focused on the topic of Abraham - Sarah (descendant), and the second one on the topic Abraham - Lot (earth). Both themes were - according to this researcher ${ }^{59}$ - unified into one cycle even before the $\mathrm{P}$ version emerged. The first version of the Abraham cycle was written in the south, in Judah, before the fall of the Kingdom of Israel. Fischer also believes ${ }^{60}$ that even before the exile, it was integrated into the Jacob cycle, and this was achieved by adding the tradition of Isaac.

Thomas Römer, ${ }^{61}$ basically collecting only the research results to date, indicates the texts as the original version of the cycle from Gen 12,10-20;13*; $16^{*} ; 18,1-16 ; 19 ; 21^{*}$. The prophetic texts from the beginning (Ezek 33,24) and the end of the Babylonian exile (Is 51,1-3) referring to the figure of the patriarch

56 E. Blum, Studien zur Komposition des Pentateuch (BZAW 189; Berlin: de Gruyter 1990) 214; idem, "Abraham I," 71-73.

57 R. Albertz, Die Exilzeit. 6. Jahrhundert v. Chr. (BE 7; Stuttgart - Berlin - Köln: Kohlhammer 2001) 193-209.

58 I. Fischer, Die Erzeltern Israels. Feministisch-theologische Studien zu Genesis 12-36 (BZAW 222; Berlin - New York: de Gruyter 1994) 339-343.

59 Fischer, Die Erzeltern Israels, 339.

60 Fischer, Die Erzeltern Israels, 343-356.

61 T. Römer, "Recherches actuelles sur le cycle d'Abraham," Studies in the Book of Genesis. Literature, Redaction and History (ed. A Wénin) (BETL 155; Leuven: Peters 2001) 189-193. 
as the ancestor of the Kingdom of Judah inhabitants - as this Swiss scholar believes - determine that in the Abrahamic tradition is considered quite archaic and its oldest literary version should be dated before this exile.

Reinherd G. Krat $\mathrm{z}^{62}$ differs from the above proposals in defining the scope and purpose of the original composition and in terms of its dating. The original version of the Abraham cycle text is limited to Gen 19 only. According to him, this text, together with other original narratives from the patriarchal tradition (Gen 26-27*: Isaac-Esau; Gen 25-31*: Jacob-Laban), formed the foundations of its earliest literary version. The first pre-Yahwist editor, active between the fall of Samaria (722 BC) and the end of the Kingdom of Judah (587/586 BC), was responsible for linking Jacob to Bethel and Isaac to Esau. in the Abrahamic tradition was only composed by the Yahwist from the Babylonian exile, who included it also in the already existing compilation of patriarchal traditions. ${ }^{63}$

Mattias Köckert ${ }^{64}$ includes the same texts as E. Blum among the original texts in the Abraham cycle (Gen 13*; 18-19; 21,1a.2*.7), but also includes Gen 16. However, it is not certain when to date the moment of integrating this chapter with the patriarchal cycle. Nevertheless, he considers relations with his eastern neighbours and offspring to be the main themes of this original cycle (cf. Ezek 33,24; Isa 51,1-3). Ultimately, he dates the relationship between Abraham and Jacob to the period preceding the exile. ${ }^{65}$

Konrad Schmid follows the findings of E. Blum. ${ }^{66}$ However, he believes that the starting point for the Abraham tradition should be the hieros logos of the former sanctuary (Terebinthen-Heligtums) in Mamre, preserved in Gen 18*. The promise of a descendant was supposed to heve been a way to legitimize neighbouring Hebron. The lack of references to the king's institution is explained by this researcher with the fact that the first composition, Abraham-Lot, was created in the context of the landed nobility circles outside Jerusalem, during the late monarchy.

As can be seen from this brief review, most researchers date the putative original version of the cycle to the monarchical period. Most also notice thematic discrepancies within the cycle, although the separation of the topics themselves and linking them to specific chapters may vary.

62 Blum, Die Komposition, 263-280.

63 R.G. Kratz, Die Komposition der erzählenden Bücher des Alten Testament (UTB 2157; Göttingen: Vandenhoeck \& Ruprecht 2000) 275-278

64 M. Köckert, "Die Geschichte der Abrahamüberlieferung," Congress Volume Leiden 2004 (VTSup 109; Leiden - Boston, MA: Brill 2006) 120-121; idem, "Wie wurden Abraham- und Jakobüberlieferung zu einen 'Vätergeschichte' verbunden?," HBAI 3 (2014) 43-66.

65 Köckert, "Wie wurden," 48-60.

66 K. Schmid, Literaturgeschichte des Alten Testaments. Eine Einführung (Darmstadt: Wissenschaftliche Buchgeselschaft 2008), 2 ed. (2014) 91-93. 
Recently, new arguments have arisen regarding the dating of the original version of the Abrahamic tradition. The already mentioned Thomas Römer in collaboration with an Israeli archaeologist Israel Finkelstein ${ }^{67}$ date the first version of the Abraham cycle to the monarchic period. Here Römer himself repeats his earlier view. However, the co-author provides him with archaeological and historical arguments to support this opinion. According to both researchers, the following arguments of a historical and archaeological nature support such pre-exile dating:

1) Archaeology shows the presence of settlements founded by people associated with Judea on the western side of the Dead Sea during the late monarchy period. This fact can justify the knowledge of the tradition of Sodom and Gomorrah (Gen 19);

2) Moabites and Ammonites lost their independence at the beginning of the 6th century BC, so references to their kingdoms (Gen 19,30-38) should be treated as a tradition from the monarchical period;

3) Ishmael in the role of Abraham's elder son, is a theme that may be associated with the expansion of the Kingdom of Judah into the southern desert areas, which was caused by the increasing imperial pressure of Assyria (7th century $\mathrm{BC}$ );

4) The tradition related to Gerar (Gen 20) may reflect the political relations and border disputes between the Kingdom of Judah and Gerar during the late monarchical period;

5) Isaac (tradition related to the region of Beersheba) as the ancestor of the people of Judah is a reflection of a situation predating the period of exile, because Beersheba was not inhabited after AD 586 BC.

It is not hard to guess that these arguments are quite speculative. Historical and archaeological data can also be interpreted in a different way, As does another Israeli researcher, Nadav Na'aman. ${ }^{68}$ In his opinion, the older version of the cycle should be dated to the period of the Babylonian exile. The first argument points to Gen 19:30-38 (origin of Moabites and Ammonites). Na'aman believes that during the monarchy, Judah did not border with Moab in the east, much less with the Kingdom of the Ammonites ${ }^{69}$ This situation changed only after the Babylonian invasion. Previously, the Ammonites lived upstream of the Jabbok River. After the Assyrian invasion of Gilead, these territories were incorporated into the Assyrian province of Kassaim. At that time, the "distance" between the lands

67 I. Finkelstein - T. Römer, "Comments on the Historical Background of the Abraham Narratives. Between 'Realia,' and 'Exegetica,'” HBAI 3 (2014) 3-23.

68 Na'aman, "The Pre-Priestly," 157-181. See also the arguments of Detlef Jericke (Abraham in Mamre. Historische und exegetische Studien zur Religion von Hebron und zu Genesis 11,27-1 9,38 [CHANE 17; Leiden - Boston, MA: Brill 2003] 232). 
of the Kingdom of the Ammonites and Judah increased even further. Moab, in turn, bordered with Israel through the Jericho region. These areas constituted a kind of buffer zone preventing entry into the territory of the Kingdom of Judah (1 Kgs 16:34; 2 Kgs 2:4.5.15.18). There was also an important Israeli sanctuary at Gilgal (2 Kgs 4:38; Hos 9:15; 12:12; Amos 4:4; 5:5). After the annexation of Samaria by the Assyrians, these territories became part of the province of Samerina, and Judah conquered them only after the decline of the Assyrian Empire. This argument is as much interesting as it is not entirely convincing. As another researcher rightly points out, ${ }^{70}$ the boundaries posed no problem for the people living in this region in their mutual contacts, especially since Moab is visible from the hills of Judah in good weather and vice versa. It is not hard to guess that the names of both neighbouring nations evoked etymological associations (Moab = "from the father"; Ammon = "the son of my relative") and made it easier to construct a popular anecdote about the origin of both nations.

$\mathrm{Na}$ 'aman's second argument relates to Ishmael as the ancestor of the nomadic tribes inhabiting the desert territories between Egypt and Judah (Gen 25:13-16). This name has been associated with the name Sumu'il known from Sennaherb and Ashurbanipal's inscriptions. ${ }^{71}$ Ernst A. Knauf called Sumu'il a confederation of tribes. He set the activity of this group in northern part of Wadi Arabah and he dated it to the period from 8th to second half of the 7th century BC. Na'aman, however, cites another researcher - Israel Eph'al, ${ }^{72}$ who believed that Sumu'il should be treated as part of the Qedarite confederation (cf. Gen 25:13), and it reached its peak of activity in the 6th century BC. However, Meindert Dijkstra ${ }^{73}$ believes that the comparison of Sumu'il - Ishmael proposed by Knauf is linguistically probable assuming that the Assyrian name is a standard misspelling of a southwestern Semitic name (such as kurSir-' $i$-la- $a$ - $a=$ Israel; yes $d I \check{s}$-me-la- $a=$ $d S a-m e-l a-a)$. Matthias Köckert also defends Knauf's thesis, ${ }^{74}$ adding a number of detailed arguments. Na'aman's assumption is, therefore, highly speculative in this case as well. Nevertheless, this split in the opinions on the issue of dating the original version of Abrahamic tradition shows how difficult it is to unequivocally determine its correct contextual situation and the time of its creation.

70 Lipschits, “Abraham,” 187-209, esp. 200, n. 54.

71 E.A. Knauf, Ismael. Untersuchungen zur Geschichte Palästinas und Nordarabiens im 1. Jahrtausend v. Chr (ADPV: Wiesbaden: Harassowitz 1985), 2 ed. (1989) 1-9.

72 I. Eph'al, The Ancient Arabs. Nomads an the Borders of the Fertile Crescent 9th-5th Centuries BC (Jerusalem: Magnes Press - Leiden: Brill 1982) 165-168. Cf. also R. Zadok, "On Early Arabians in the Fertile Crescent," TA 17 (1990) 223-224. The latter researcher considers such identification to be "non-philological."

73 M. Dijkstra, "Ishmael," $D D D, 451$.

74 M. Köckert, "Hagar und Ismael. Politische Aspekte im Wandel der Überlieferungen," The Politics of the Ancestors (eds. M.G. Brett - J. Wöhrle) (FAT 124; Tübingen: Mohr Siebeck 2018) 233-258. 


\subsubsection{Some Critical Remarks}

Let us summarize, then, what the status quaestionis is in the search for the oldest version of the Abraham cycle. The above-mentioned researchers perceive Gen $12-13 ; 16 ; 18: 1-15 ; 19 ; 21$ (start of the chapter) as the oldest literary layer in the cycle. Most also date it to the late monarchy period (after $722 \mathrm{BC}$ ). The main themes of this original cycle are: offspring, land, ethnic origin of Israel and its relationship with its neighbours in the east and south. In this group of texts, a certain logical narrative sequence can be found in Gen 13; 18-19 (Abraham - Lot Sodom), in the Abrahamic tradition's stay in Egypt (Gen 12:10-20) and the tradition of the Egyptian woman Hagar $(16 ; 21)$ give the impression of separate narrative threads. Both are connected by a clearly positive attitude to Egyptians and, in a sense, a critical attitude towards an overly nationalistic perspective of the exodus tradition. Researchers refer to them as counter history (Ger. Gegegengeschichte). In Gen 12:17 Yhwh "strikes" (ng'; Exod 11:1) the Pharaoh, as in the story about exodus, but this time the ruler behaves in a correct way and sends Abraham (šlh; cf. Exod 5:1-2; 7:2.14-16.26-27 etc.) back to Canaan without taking from him what he had previously given him in exchange for Sarah. Discreetly but clearly, there is a dispute with the official, Deuteronomist concept of the exodus, and as Thomas Römer sums up this pericope "the Pharaoh is better than the news tells." ${ }^{75}$ Similar tendencies are also found in Gen $16 .{ }^{76}$ This time the Egyptian woman Hagar is "oppressed" ( $n h$; cf. Exod 1:11-12; then also Gen 15:13; Deut 26:6) by her Hebrew mistress and, like the Israelites from Egypt, it is now her turn to "flee" (Gen 16:6: brh; cf. Exod 14:5) from this oppression. According to some researchers, Hagar is stylized here to be a "female Moses." 77 Besides the mal'ak Yhwh theme (cf. Gen 16:7; Exod 3:2) in both cases, these heroes have their freedom ensured (Israel/Ishmael) and in both situations Yhwh sees (Exod 3:7) or hears (Gen 16:11) the "oppression" of ( 'onî) Israel/Ishmael.

Thus, both pericopes ${ }^{78}$ have a two-part structure marked by a change of place (Gen 12:10-13: path to Egypt; 12:14-20; stay in Egypt; 16:7-13: in the desert) and similar, non-standard beginning $(12: 11 ; 16: 2$; marked by the hinneh-nā' formula). In Gen 12 Abraham speaks, and it is Sarah who is silent and shows obedience; in Gen 16 Sarah speaks, and Abraham obeys. Finally, in both pericopes,

75 Römer, "Die politische," 226.

76 T.B. Dozeman, "The Wilderness and Salvation History in the Hagar Story," JBL 117 (1998) $23-43$.

77 Römer, "Die politische," 226.

78 On the stylistic and literary relations of the pericopes from Gen 12:10-20; 16:1-2.4-8.10-13 (for the reconstruction of the latter, cf. Knauf, Ismael, 25-35; T. Römer, "Isaac et Ismaël. Concurrents ou cohéritiers de la promesse? Une lecture de Genèse 16," ETR 74 [1999] 162-164) is especially highlighted by John Van Seters (Abraham, 168-170, 192-194). 
the initial attempt provokes later complications, the solution of which is only possible through the intervention of Yhwh or his messenger.

All these similarities suggest that both pericopes were penned by the same author. The time of their creation is difficult to determine. Perhaps they were written as an addition to the Abraham-Lot story. Both scenes and the themes contained in them may in any case belong to the pre-P tradition, because in Gen $17^{*}$ (P) the knowledge about two Abraham's sons from Gen 16 and Gen 18:1-15 is taken for granted and attempts are made to answer the question of how to properly distinguish between them. ${ }^{79}$

Nevertheless, in Gen 12:10-20 there is no figure of Lot, who is mentioned before and after this pericope. Therefore, it is difficult to combine it as an element originally connected with the Abraham-Lot-Sodom cycle. ${ }^{80}$ On the other hand, the character of Hagar fits well with the theme of the promise of offspring present in the cycle but does not necessarily belong to the original version. If anything, it fits better the narrative line of P (cf. Gen 17). Nevertheless, some researchers classify the Hagar tradition among the potential texts belonging to the oldest literary tradition in the cycle. Most of them, however, date Gen 12:10-20 and Gen 16 to the time of the Babylonian exile - mainly because of the above mentioned "critical" perspective towards the exodus tradition common to both pericopes - attributing both texts to the same author or community. ${ }^{81}$ In Gen 12:10-20 - as we have noted - the figure of Lot does not appear (cf. Gen 12:4-5; 13:1). Moreover, this chapter has all the data to deserve being treated, not only as a separate tradition, but also as an independent literary unit. However, the stance whereby Gen 12:10-20 is the oldest version of the "wife-sister" theme is not adhered to nowadays. It is rather Gen 26 that is regarded as such. ${ }^{82}$ The placement of this pericope in its present location can also be read as an attempt to polemicize against the Egyptian diaspora (Gen 12:10 and Jer 41-42).$^{83}$ Abraham's place is

79 Römer, "Die politische," 225, 227.

80 On the one hand, that pericope seems to include the oldest version of the "wife-sister" theme (cf. V. Golinets, "Die Gefährdung den Ahnfrau. Anmerkungen zu literarischen Abhängigkeiten in der Versionen von Genesis 12; 20; 26," Nächstenliebe und Gottesfurcht. Beiträge aus alttestamentlicher, semitistischer und altorientalistischer Wissenschaft für Hans-Peter Mathys zum 65. Geburtstag [eds. H. Jenni-M. Saur] [AOAT 439; Münster: Ugarit-Verlag 2016] 91-114), and on the other hand, this text (along with Gen 16) is referenced as a type of polemic with the tradition of the exodus; cf. T. Römer, "Exodusmotive und Exoduspolemik in den Erzvätererzählungen," Berührungspunkte. Studien zur Sozial- und Religionsgeschichte Israels und seiner Umwelt. Festschrift für Rainer Albertz zu seinem 65. Geburtstag (eds. I. Kottsieper - R. Schmitt - J. Wöhrle) (AOAT 350; Münster: UgaritVerlag 2008) 3-19.

81 Lipschits-Römer-Gonzalez, “The Pre-Priestly,”261-296, esp. 292-295; Lipschits, “Abraham,” 196.

82 Römer, "Die politische," 227.

83 Blum, Die Kompostion, 311; J. Wöhrle, "Abraham und das Leben im Ausland: Zur Intention der Ahnfrau-Erzählung in Gen 12, 10-20 und ihrer frühen inner- und ausserbiblischen Rezeption," 
not in the land of the pharaohs, but in the land that Yhwh promised the patriarch and his posterity. ${ }^{84}$

The story of the rescue of Isaac and Hagar in Gen 21:8-21 is clearly parallel to Gen 22:1-19. Thus, both chapters can be attributed to the same author or Gen 21:9-21 can be considered to be later than Gen $22 .{ }^{85}$ In both pericopes Abraham's descendant (Ishmael and Isaac respectively) is threatened and in both the individual parents (mother and father respectively) play an important role in his rescue. Apart from the structural similarity (threat - rescue) there are then also a number of linguistic arguments supporting this opinion. ${ }^{86}$ So, we are dealing with a later text. Without doubt, however, Gen 21,8-21 takes up an earlier theme, already present in Gen $16^{*}$. It is therefore an editorial expansion ${ }^{87}$ which clearly justifies the distinct lifestyle of the Ishmaelites. The correction may have been made because they had already been linked to Abraham. ${ }^{88}$ There is a parallel between Gen 21:22-34 (Abimelech's shepherds' conflict with Abraham) and Gen 26:14b-33, but it is difficult to rule on the chronological priority of either scene over the other. Some scholars, however, believe that Gen 21 was written under the influence of Gen 26 (the transfer of tradition from Isaac to Abraham). ${ }^{89}$

It is much more difficult, however, to assess the origin and thus to establish the dating of Gen 16. The issue of a son being born (Gen 16:1-3-4a.15) has its parallel in the report of the birth of Isaac (Gen 21:1-8*). The latter text clearly already presupposes the former one. However, scholars are looking for an earlier version (especially the above-mentioned 2.7). ${ }^{90}$ The theme of a son being born may therefore be earlier, although not necessarily linked to the person of Abraham from the beginning. In Gen 18:1-15 the figure of Ishmael is not yet taken into consideration at all (P already knows the tradition of two sons; cf. Gen 17). From this we can conclude that Gen 16 was written later or at least in a different

BN 151 (2011) 32-33; Lipschits - Römer-Gonzalez, "The Pre-Priestly,”293; Lipschits, “Abraham," 202; Römer, "Die politische," 227.

84 Blum, Die Komposition, 311; Wöhrle, "Abraham und das Leben," 23-46; Lipschits, "Abraham,” 201.

85 I. Fischer, "Möglichkeiten und Grenzen historisch-kritischer Exegese. Die «Opferung» der beiden Söhne Abrahams: Gen 21 und 22 im Kontext," Streit am Tisch des Wortes? Zur Deutung und Bedeutung des Alten Testaments und seiner Verwendung in der Liturgie (ed. A. Franz) (Pietas Liturgica 8; St. Ottilien: EOS 1997) 17-35.

86 Blum, Die Komposition, 314-315; Fischer, Die Erzeltern, 333-335; Mühling, Blickt, 66, n. 207.

87 Kratz, Die Komposition, 278

88 A. de Pury, “Abraham. The Priestly Writer's 'Ecumenical' Ancestor," Rethinking the Foundation. Historiography in the Ancient World and in the Bible. Essays in Honour of J. Van Seters (eds. T. Römer - S.L. McKenzie) (BZAW 293; Berlin - New York: de Gruyter 2000) 163-181.

89 L. Schmid, "Die Darstellung Isaaks in Genesis 26,1-33 und ihr Verhältnis zu den Parallelen in den Abrahamerzählungen," Gesammelte Aufsätze zum Pentateuch (ed. L. Schmid) (BZAW 263; Berlin: de Gruyter 1998) 167-223; L. Ruppert, Genesis. Ein kritischer und theologischer Kommentar. III. Gen 25, 19-36, 43 (FB 106; Würzburg: Echter 2005) 102-105.

90 Köckert, "Die Geschichte," 121. 
context. ${ }^{91}$ The rest of the story, however, already gives the impression of editorial additions from the exile period or later. ${ }^{92}$ On the other hand, there is a noticeable tension between Gen 16.12 (non-P), where Ishmael is described as living in the wilderness, and Gen 16:15 (P), where he returns and lives in Abraham's house..$^{93}$ In addition, Gen 16 (together, by the way, with Gen 14-15.17) interrupts the natural and probably original course of events between Gen $12-13.18-19 .{ }^{94}$ All these chapters "inserted" between this narrative line are linked to $\mathrm{P}$ or post-P, ${ }^{95}$ which of course does not exclude the fact that some motifs, such as that of Hagar and her son, may have been older (e.g., the legend of the origin of the Hagarites or a reflection of some current political reality ${ }^{96}$ ) and only used over time in the Abraham cycle. As we have already noted, it may have been included at the same time as Gen 12:10-20. The author of the pericope of Gen 16 was aware of the coexistence of the Judeans and other semi-nomadic groups in the Hebron region. Perhaps they were also connected by visiting the common sanctuary at Mamre. By means of the story of Hagar, however, he may have wanted to demonstrate the "superiority" of the former over the other groups. Here, the term "Ishmael" may be the exonym of all semi-nomadic groups to the south and east of Hebron and those staying in the territory of Judah. ${ }^{97}$ The presence of numerous such groups in this region is attested in the Assyrian sources of the 8 th and 7 th centuries $\mathrm{BC}$ mentioned above. ${ }^{98}$ These groups probably formed the aforementioned coalition of Arab tribes, referred to in the Assyrian texts from the times of Sennacherib and Ashurbanipal with the term Shumu'il. ${ }^{99}$ But should the name Ishmael be linked to this Assyrian term? We have already mentioned the doubts raised by some scholars. ${ }^{100}$ Nevertheless, the difficulties of linguistic nature can be reasonably resolved and this identification seems the most appropriate today, although one no longer

91 Römer, "Die politische," 224.

92 Cf., inter alia the discussion in: C. Levin, Der Jahwist (FRLANT 157; Göttingen: Vandenhoeck \& Ruprecht 1993) 146-152; Lemański, Księga Rodzaju, 259-261.

93 Knauf, Ismael, 18-19; Köckert, “Gen 20-22,” 166-173.

94 Kratz, Die Komposition, 263-264

95 R. Kratz, "The Pentateuch in Current Research: Consensus and Debate," The Pentateuch (eds. T.B. Dozeman - K. Schmid - B.J. Schwartz) (FAT 78; Tübingen: Mohr Siebeck 2011) 47, n. 50 with literature.

96 On the Egyptian inscription of Darius the Great, the term "Hagar" means Arabs inhabiting the southern part of the Levant, while the term "Maka" means eastern Arabia; E.A. Knauf, "Hagar," ABD III, 18-19; R. Hendel, "Politics and Poetics in the Ancient Narratives," The Politics of the Ancestral (eds. M.G. Brett - J. Wöhrle) (FAT 124; Tübingen: Mohr Siebeck 2018) 23-24.

97 Lipschits, "Abraham," 202.

98 I. Eph'al, “Ismael' and Arab(s)': A Transformation of Ethnological Terms," JNES35 (1976) 225-235, esp. 225-229; idem, The Ancient Arabs, 233-240; Knauf, Ismael, 5-81.

99 Knauf, Ishmael, 1-10; idem, "Ishmael (Son of Abraham and Hagar) I: Hebrew Bible/Old Testament)," EBR XIII, 352-355.

100 Eph'al, The Ancient Arabs, 166, 168; Naam'an, “The Pre-Priestly,” 162-163; also Zadok, "On Early Arabians," 223-231, esp. 223-224. 
speaks of a loose confederation of tribes, but of a group of clans. The existence of this group is therefore a terminus a quo for the dating of Gen 16. However, if this pericope is from the same author as Gen 12:10-20, then it too should be dated to the period of the Babylonian exile. But is it meant to advertise the patriarch to the surrounding Arab communities in the vicinity of Hebron? ${ }^{101}$ In Gen 16, despite the indication of common descent (same father), these groups are placed in a position inferior to the inhabitants of Judea (different mothers). The choice of Hagar - the "Egyptian slave" has probably not been made here by accident. Apart from a common origin, they were linked with the population of Judah by a common cult, which allows for providing the etymology of the name "Ishmael" in connection with the name of Yhwh - "...because Yhwh heard $(\check{s} m$ ') when you were humiliated" (Gen 16:11b). This popular etymology is based on the juxtaposition of Yhwh with the verb stem $\check{s} m$ '. It also shows that Yhwh is identified here with El (Ishma-El) and is not only the God of Abraham and Isaac, but also the God of Hagar and Ishmael. ${ }^{102}$ Thus, Abraham was not only a local figure with whom a specific place of residence and worship in Mamre was connected. Through his association with Ishmael he turned into the father of many other ethnic groups and local tribes. Later, priestly additions place clear emphasis on the fact that the groups represented by Isaac and Ishmael do not, however, belong to the same ethno-cultural community. ${ }^{103}$

\subsubsection{The Abraham-Lot-Sodom Story as the First Stage in the Formation of the Abraham Literary Tradition}

In the search for the oldest elements of the Abrahamic tradition, the customs described in the cycle dedicated to him were compared above all with those found in the texts from Nuzi, Mari and Ebla. ${ }^{104}$ The alleged similarities allowed for placing the biblical traditions about this patriarch in the context of the migration processes in the second millennium BC. ${ }^{105}$ Monographic studies from the mid1970s (e.g. by John Van Seters, cited here) demonstrated, however, that such customs were in force in both the second and first millennium BCE and do not

101 This is in the form of a conjecture by Thomas Römer ("Die politische," 228).

102 Lipschits, “Abraham,” 203. Later also J. Lemański, „Hagar - Matka niewybranych?,” „Niewiaste dzielna kto znajdzie?" (Prz 31,10). Rola kobiet w biblijnej historii zbawienia (eds. A. Kubiś K. Napora) (Lublin: Wydawnictwo KUL 2016) 29-51.

103 Lipschits - Römer - Gonzalez, "The Pre-Priestly," 271-273.

104 On the significance of the texts discovered there for the research on the ancestors of Israel, cf. B.L. Eichler, "Tabliczki z Mari”; “Tabliczki z Nuzi," Stownik wiedzy biblijnej (eds. B.M. MetzgerM.D. Coogan) (Warszawa: Vocatio 1997) 754-755; P.B. Machinist, "Ebla," Encyklopedia biblijna (ed. P.J. Achtemeier) (Warszawa: Vocatio 1999) 233-236.

105 Cf. J. Bright, Historia Izraela (trans. J. Radożycki) (Warszawa: Pax 1994) 77-88. 
provide a convincing argument for the early dating of the Abrahamic tradition (Bronze Age).

Following the suggestion of many scholars, we can consider the chapters related to Sodom and Lot as the starting point for the search for the original version of the Abraham story. The first texts that can be taken into account as starting elements in the formation of the cycle about Abraham are found in Gen 13* and $18 *-19 *$. The pericope dealing with the destruction of Sodom (Gen 19) has many connections with Gen 18. ${ }^{106}$ The etiological ending (Gen 19:30-38) gives the story a distinctly "(inter)national" character and makes us look at the events described in Gen 19 from the perspective of the Kingdom of Judah and its inhabitants. ${ }^{107}$ This is an evident "nationalisation" of the so far local tradition. It is worth noting that the destruction of Sodom and Gomorrah is mentioned many times in the Hebrew Bible (Deut 29:22; 32:32; Isa 1:9-10; 3:9; 13:19; Jer 23:14; 49:18; 50:40; Ezek 16:44-48; Amos 4:11; Zeph 2:9), but never in connection with Lot. The tradition itself could therefore be archaic, even mythical, and it referred to the destruction of old cities, which explained etiologically the current "lunar" appearance of the Dead Sea region. The symbolic perception of this chapter as a reminiscence of the destruction of Jerusalem appears less likely due to the frequent references to this tradition in the biblical texts. Moreover, in Gen 19 , the etiological interests are clearly visible. ${ }^{108}$ Along with undertaking this chapter by the biblical author, Lot, the legendary forefather of the Ammonites and Moabites, was integrated with it. It is interesting, however, that we are not able to say anything about the origins of the Lot tradition. We also do not know the etymology of his name (the root $l w t$ carries the meaning of "hiding," "covering," "concealing"). Therefore it can be concluded that all of this was known at least to the addressees of the first version of the Abraham-Lot cycle or that the character of Lot is only symbolic and was invented in order to separate oneself from the inhabitants of the eastern bank of the Jordan. Abraham and Lot share three main themes in this cycle: land (Abraham and Lot live on the opposite banks of the Jordan), hospitality (Abraham in Gen 18, Lot in Gen 19) and offspring (promised descendant; Ammonites and Moabites). ${ }^{109}$ The tone of this original narrative was peaceful and demonstrated a friendly attitude towards its eastern neighbours. The excerpt from Gen 19:30-38 - if we accept the arguments of Nadava Na'aman, quoted earlier, - though it may be later in relation to the rest of the pericope, similarly to the introduction from Gen 13.

\footnotetext{
106 Van Seters, Abraham, 215-216; Blum, Die Komposition, 280; Römer, "Die politische," 222-223.

107 Kratz, Die Komposition, 276; Mühling, Blickt, 42.

108 However, Jericke, Abraham, 303-304; cf. a more cautious opinion of Nadav Na'aman ("The PrePriestly," 167-168); Römer, "Die politische," 223.

109 Lipschits - Römer - Gonzalez, "The Pre-Priestly,” 284-290; Lipschits, “Abraham,” 200.
} 
In fact, in the aforementioned connection between Gen 18-19, it is not difficult to notice the parallelism between both chapters. It implies a generally positive image of Lot (hospitality), although not without a noticeable tendency to deteriorate his assessment in the course of further events. The most important difference that influences these tendencies is the contrast between living in a tent (Abraham) and in the city (Lot sits at the city gate and has a house within its walls; cf. Gen 13:12; 19:1-2). Lot - just like Abraham prepares a bountiful feast for his guests, but only in the case of the former it is referred to as mištteh, a feast with wine or other alcoholic beverages. The image of the "evil city" clearly deteriorates here (cf. Gen 13:13), and this negative assessment will only deepen along with further events.

Chronologically, the first references to Abraham, apart from the Pentateuch, relate to the theme of land (Ezek 33:24) and offspring (Isa 51:2). Therefore, Abraham - the local ancestor of the inhabitants of Hebron and the surrounding area was considered to be the "first" owner of this land, and later as someone to whom a son was promised (only then would he be identified with Isaac, and the tradition of the second son would appear). Both mentioned texts, however, suggest above all that the character of Abraham constituted a reference point for those who remained in Judea during the Babylonian Captivity and faced the challenge of the multi-ethnic population of these lands and their immediate vicinity. These observations lead some researchers even to believe that the author of Isa 51:2 may already have known the priestly tradition of Abraham. ${ }^{110}$ The destruction of the monarchical and cult-identity centre in Jerusalem may indeed have paved the way for local tradition to become the foundation of the pan-Israel story of the three patriarchs. At that time, apart from Hebron, there could have been many potential local centres and various traditions related to them, which had not been yet admitted to the official circle of traditions. We could mention for instance Mizpah, Betel or Gibeon. ${ }^{111}$ The Hebrew Abrahamic tradition about was focused on its pre-exile version at least on land and progeny, and the starting point was the theme of hospitality. "The close relationship between 'one' Abraham and the land is not justified here by the promise of the land, but by [the fact] that he owned this land." 112 Moreover, in Ezek 33:24, when this fact is mentioned, Abraham is not yet connected with Jacob, although the latter is known to Ezekiel (Ezek 28:25; $37: 25)$ and also this character remains in the relationship with this land. From the exiles' perspective, the postulates of the people remaining

110 Köckerct, "Die Geschichte," 110. T. Römer, "Abraham Traditions in the Hebrew Bible outside the Book of Genesis," The Book of Genesis, Views the Thesis as Unproven. Composition, Reception, and Interpretation (eds. C.A. Evans - J.N. Lohr - D.L. Petersen) (VTSup 152; Leiden - Boston, MA: Brill 2012) 159-180, esp. 166-169.

111 Lipschits, "Abraham," 201.

112 Quotation and clarification from Lipschits, „Abraham,” $201+$ n. 60. 
in Judea and claiming land rights with regard to Abraham were unacceptable. The $\operatorname{root} j r \check{s}$ - "take possession/inherit" applied by Ezekiel (Ezek 33.24) in reference to Abraham is scarce in the cycle about this patriarch (Gen 15; 22:17; 24:60), and the meaning of "inherit" is visible in Gen 15:3-4; 21:10. It could, however, have been taken from this prophet's statements. ${ }^{113}$ However, Ezekiel's polemical tone towards the end of the exile was replaced by a positive message to "the inhabitants of the ruins" (Isa 51:1-3). This time, however, it does no longer concern the land, but the numerous offspring.

Only towards the end of the existence of monarchy could the inhabitants of Judah come into direct (i.e. trans-border) contact with the Moabites and the Ammonites. Nevertheless, as we have observed, boundaries were not a problem with regard to maintaining mutual contacts. In the original version of the cycle, Abraham has only one promised son. A different first-born son, Ishmael, appeared only with the addition of the character of Hagar. Successive editors, however, soon decide to exclude him, as they will do now with Lot, from the rights to inheritance after Abraham. The figure of Lot originally allows one only to express the awareness of some common ethnic roots in relation to the two neighbouring nations, thought to have descended from him. However, both in the original version as well as in the later changes, Lot and his progeny are clearly cut off from the chosen line of Abraham's descendants. Political and territorial considerations were not the whole picture here. This estrangement also implies the symbolic separation of Lot (and thus his descendants) from what is honorary (such Lot's attitude in Gen 13:7-11) and civilised (as in Gen 19144). Therefore, Lot's attitude in the first version is presented as "a moral breakthrough in social structures." A further expansion of Lot's storyline (P/non-P) only deepens this perception of the Moabites and Ammonites' ancestor.

In Gen 18 and 21:1-7* Abraham and Sarah become the parents of a son who already has a specific name: Isaac. This name identification is also located through

113 Römer, "Die politische," 217.

114 Robert Alter ("Sodom as Nexus: The Web of Design in Biblical Narrative," The Book and the Text. The Bible and Literary Theory [ed. R. Schwartz] [London: Blackwell 1990] 151) he classifies the attitude of the inhabitants of Sodom as a "biblical version of anti-civilization." Lot's behavior also gradually undergoes degradation in this chapter. This motif, which depreciates him, is later developed by later additions; cf. Hendel, "Politics," 20-23. Thomas Römer ("Die politische," 224) treats the story of the flight as a kind of burlesque, pointing to his article; cf. T. Römer, "Lot, l'hospitalité et l'inceste," Tabou et transgressions. Actes du colloque organisé par le Collège de France, Paris, les 11-12 avril 2012 (ed. J.M. Durant) (OBO 247; Friborg - Göttingen: Vandenhoeck \& Ruprecht 2015) 135-144.

115 Hendel, "Politics," 22. Nevertheless, the will to hand over one's own daughters to disgrace, only to defend their guests, or then to give birth to the father's descendant through an act of incest, must be assessed in the context of that time, and not from the point of view of current morality. This is especially true of the first of these events; Thomas Römer rightly points it out in "Die politische," 224-225. 
the word play related to the etymology of the name "Isaac" (Gen 17:17; 18:10b-15; 21:7). Above all, however, by involving God's intervention and His promise of progeny into the course of events. After Lot (Moabites and Ammonites), this is the next step in the process of "nationalising" the Abraham-Lot-Sodom tradition. This time it is achieved by including the figure of Isaac in the Abrahamic tradition. ${ }^{116}$ From the fact that Isaac is the only possible fulfilment of the promise of a son in the narrative, it is concluded that the Abraham-Isaac connection predated the Abraham-Jacob connection. ${ }^{117}$

The aforementioned two statements of the prophet Amos (Amos 7:9.16) are intriguing. These are probably passages which precede the final fall of Israel (722 BC). ${ }^{118}$ They indicate that the (royal?) synonym for the south (for the Israelites) was precisely "house of Isaac" (vs. "house of Jeroboam"). The place of worship at Beersheba, associated with him, also had some significant references for them. Since Isaac, and not Abraham, was a figure identified with the south (Judah), or at least with some south-western region in relation to Israel, it can be assumed that the figure of Isaac appeared here not only because of the need to connect the traditions of Abraham and Jacob, but also to strengthen Abraham's status as a representative of all Judea, not just its south-eastern part. Let us recall that Abraham is rarely mentioned anywhere else than in the Pentateuch, and if it is, those are texts from the period of exile or more later ones. ${ }^{119}$ Before the exile, the Patriarch was not perceived, like Jacob in Israel (cf. Gen 32:23-32), as the "father of the nation." ${ }^{120} \mathrm{He}$ does not even represent any local clan or tribe. Neither does he have any features typical of a royal figure. This may explain the fact that the patriarch is not mentioned either in the Deuteronomist tradition or in the Book of Jeremiah. ${ }^{121}$ This is the main argument for treating the literary tradition of Abraham in the Pentateuch as a text written in its original form no earlier

116 Originally, this figure was associated with Ephraim (the Kingdom of Israel); cf. J. Lemański, "W poszukiwaniu tradycji o Izaaku," Colloquia Theologica Ottoniana 2 (2013) 63-76; T. Römer, "Isaac (Patriarch) I. Hebrew Bible/Old Testament," EBR XIII, 260-266.

117 Römer, "Die politische," 224.

118 At this point, it is worth recalling what was mentioned earlier. Israel developed faster as a monarchy than Judah (Iron Age IIA vs. Iron Age IIB-C). On the one hand, in the 9th century BC we already have a strongly shaped Kingdom of Israel with its founding traditions, and on the other hand, we can speak about the status of a strong (in the regional context) Kingdom of Judah only at the turn of the 8 th/7th century BC. In addition to the previously quoted literature, see also Z. Herzog - L. SingerAvit, "Redefining the Center: The Emergence of State in Judah," TA 31 (2004) 209-244.

119 Isa 29:22;41:8;51:2;63:16; Jer 33:26;Ezek33:24;Dan3:35;Mic 7:20;Ps 47:10; 105:6.9.42;2Chr 20:7.

120 Such an identification could have occurred at the times of Jeroboam II, and the critical statement in Hosea 12 may be about giving such "official status" to the person of Jacob; Thomas Römer's view, "Die politische," 218-219. It is noteworthy that in Abraham's case changing the name, differently than in the case of Jacob, does not make him a representative of Judea, but the father of many nations.

121 Jer 33:14-26 (missing in LXX) does mention Abraham (Jer 33:26), but the text is considered a later gloss which distinguishes between the "descendants of Jacob" (Israel) and the "descendants of David” (Judah); cf. Lipschits, ,Abraham,” 198, n. 46. 
than in the 7th or in the 6th century BC. ${ }^{122}$ Some even claim that it is a composition entirely dependent on the version of $\mathrm{P} .{ }^{123}$ The establishment of the Abraham-Isaac line could in every case enrich the very tradition of Abraham with new themes and endow Abraham with more than just local prestige. What can be said for sure, however, is that the figure of Abraham became prominent at a rather late period, and the genealogical order: Abraham - Isaac - Jacob is an effect and a resultant of the changing political and social situation. One may even risk the statement that the patriarch of the least importance in the early period of forming the tradition of ancestors had risen to the rank of the most important of them. Oded Lipschits ${ }^{124}$ believes that the reason for this was that this local tradition was ignored by the Jerusalem elite. Only the deportation of this elite reconstructed the way to lead this figure out of its local milieu (cf. Ezek 33:24). First in the form of a representative ${ }^{125}$ of the south, then of all Israel.

The Jacob tradition had taken its literary shape much earlier (cf. Hos 12), ${ }^{126}$ and the same patriarch - the main ancestor and eponym in the tradition of the origins of Israel, was a figure considered to have been the first ancestor also by the authors from Judah. ${ }^{127}$ It is therefore not surprising that many motifs from this very tradition were used in the creation of the literary version of the patriarchal cycles in the story of Abraham.

However, not all the themes present in the Abraham cycle were borrowed from the tradition of Jacob or Isaac and elaborated in favour of Abraham. The double name (Abram - Abraham) is probably an innovation of priestly authors (Gen 17:5 = P), following the motive of changing the name from the tradition of

122 A view held by, among others, D. Carr, Reading the Fractures of Genesis. Historical and Literary Approaches (Louisville, KY: Westminster John Knox 1996) 203-204; Kratz, Die Komposition, 279. Albert de Pury, already quoted in this way, "Abraham," 163-181; idem, " $\mathrm{P}$ ' as the Absolute Beginning," Les dernières rédactions du Pentateuque, de l'Hexateuque et de l'Ennéateuque (eds. T. Römer - K. Schmid) (BETL 203; Leuven: Peeters 2007) 99-128.

124 Lipschits, „Abraham,” 187-209, esp. 198.

125 Jacob represents the North and Abraham the South in many texts, mostly prophetic ones (Jer 29:22; 41:8; 63:16 [Abraham and Israel]; Mic 7:20; Ps 105:6), but in the opinion of scholars they all belong to the post-exile editing.

126 However, as mentioned previously, the decisions regarding the dating of the text by Hosea are different. It is dated to the 8th century BC by among others A. de Pury, "The Jacob Story and the Beginning of the Formation of the Pentateuch," A Farewell to the Yahwist? The Composition of the Pentateuch in Recent European Interpretation (eds. T.B. Dozeman - K. Schmid) (SymS 34; Atlanta: SBL 2006) 51-72; E. Blum, "Hosea 12 und die Pentateuchüberlieferungen," Die Erzväter in der biblischen Tradition. Festschrift für Matthias Köckert (eds. A. Hagedorn - H. Pfeiffer) (BZAW 400; Berlin: de Gruyter 2009) 291-321. A later time of its origin is indicated by Susanne Rudnik-Zelt (Hosea studien. Redaktions-kritische Untersuchungen zur Genese des Hoseabuches [FRLANT 213; Göttingen: Vandenhoeck \& Ruprecht 2006] 68-72, 261-278) and James M. Bos (Reconsidering the Date and Provenance of the Book of Hosea. The Case for Persian-Period Yehud [New York: Bloomsbury Clark 2013] 998).

127 J. Blenkinsopp, Abraham. The Story of a Life (Grand Rapids, MI, Cambridge: Eerdmans 2015) 1-15; J. Lemański, “Abraham versus Jakub," Collectanea Theologica 88/4 (2018) 35-51. 
Jacob. The purpose of this change could be primarily the desire to introduce royal connotations to the tradition of the patriarch (Gen 17:6). ${ }^{128}$ On the other hand, it cannot be ruled out that it was the priestly authors who introduced the motif of changing the name also to the Jacob tradition (cf. Gen 35:10), ${ }^{129}$ although this version of events seems less probable (cf. Gen 32:28-29).

From the oldest editorial layer postulated by researchers in the Abraham cycle, an image emerges that can be treated by us, with high probability, as a kind of hieros logos of the sanctuary known as "terebinths/oaks of Mamre near Hebron" (Gen $13: 18 ; 18: 1 ; 23: 17.19 ; 25: 9 ; 49: 30 ; 50: 13$ and Gen 14:13.24 as a personal name; cf. also 2 Sam 5:3). It cannot be ruled out that even the first reworking of this tradition (TM: many trees) was aimed at lowering the cult aspects of this former sanctuary "under the tree" (LXX; Peshitta retain the singular form here). ${ }^{130}$ Mamre is mentioned nowhere else outside the Book of Genesis. It cannot be ruled out that the reason for this was the fact that this sanctuary was treated as an unorthodox place of worship. Perhaps it was the same sanctuary where Absalom wanted to go in order to fulfil his vows "for Yhwh in Hebron"131 (2 Sam 15:7; cf. 3:2-3: Absalom's birthplace). Perhaps, since it was treated as a place of unorthodox worship, it was also ignored by the Deuteronomist. However, Hebron itself is considered an important place in the tradition of King David. Here he was crowned king in Judah (2 Sam 2:4) and possibly also king in Israel (cf. 2 Sam 5:1). ${ }^{132}$ However, the similarities between the figures of Abraham and David are an idea characteristic only of the post-exile texts. Likewise, the boundaries of the purported empire from the time of David/Solomon (cf. Gen 15:18) in fact constitute a reflection of the geopolitical realities of Persian times (cf. also $2 \mathrm{Kgs} 24: 7$ ). ${ }^{133}$ Today we are not sure where this sanctuary might have been located. According to Gen 13:18, it was situated near Hebron. The identification of this place with the tomb of the patriarchs in Machpelah is rather secondary (cf. Gen 23:17.19; $25: 9 ; 49: 30 ; 50: 13 \mathrm{P}$ or post-P). So far, there are no convincing arguments to assume that there was any primordial source of this tradition (e.g. the tomb of

128 Finkelstein -Römer, "Comments," $9+$ n. 24.

129 Wöhrle, Fremdlinge, 88-90.

130 C. Westermann, Genesis. II. Genesis 12-36 (BK 1/2; Neukirchen-Vluyn: Neukirchener Verlag 1981) 199.

131 Cf. 1 Sam 5,5: "Dagon in Aszdod:" and "Yhwh of Samari," "Yhwh of Teman" in the texts of Kuntillet 'Ayrud.

132 Cf. A. Lemaire, "Cycle primitif d'Abraham et contexte géographico-politique," History and Traditions of Early Israel. Studies Presented to Eduard Nielsen (eds. A. Lemaire - B. Otzen) (VTSup 50; Leiden: Brill 1993) 62-75.

133 M. Köckert, Vätergott und Väterverheissungen. Eine Auseinandersetzung mit Albrecht Alt und seinen Erben (FRLANT 142; Göttingen: Vandenhoeck \& Ruprecht 1988) 276-299; T. Römer, "Abraham and the Law and the Prophets," The Reception and Remembrance of Abraham (eds. P. Carstens - N.P. Lemche) (PHCS 13; Piscataway, NJ: Gorgias 2011) 103-118; Finkelstein Römer, "Comments," 3-4. 
an important ancestor as a place of worship). ${ }^{134}$ However, it cannot be ruled out that the authors who introduced this new identification aimed at desacralizing Mamre itself as a former place of worship. ${ }^{135}$ The present location of the biblical Mamre in Haram Ramet Khalil, $3 \mathrm{~km}$ from Hebron, dates from Roman times (Herod the Great) and has little to do with an actual biblical-era sanctuary. ${ }^{136}$ Similarly to Khirbet Nimra (Mamre - Nimra: sounds similar), the complex dates back to Persian times, but it lacks a noticeable altar or any other cult installation. ${ }^{137}$

The scene in Gen 18:1-15, i.e. the memory of God's visit, receiving Him by the patriarch and obtaining in return the promise of a descendant, may constitute the beginning of the Abrahamic tradition (cf. Gen 15:3-4). It is difficult to pinpoint the timing of this original story, but it is quite likely that it may even go back to the times preceding the rise of the monarchy. The nameless descendant may have been the first subject of this initial version of the story. It cannot even be ruled out that initially this story did not refer to Abraham at all. The promise of a son out of gratefulness for hospitality is a theme already known from Deuteronomist literature (cf. $2 \mathrm{Kgs} \mathrm{4:8-17).} \mathrm{In} \mathrm{combination} \mathrm{with} \mathrm{God} \mathrm{in} \mathrm{the} \mathrm{role} \mathrm{of}$ a guest, it could have been the aforementioned hieros logos of the local sanctuary. With the adaptation of this hieros logos to in the Abrahamic tradition, the theme of the descendant became the starting point for his somewhat later identification with Isaac. In the series about Abraham, Isaac clearly remains only a background figure. It is mainly mentioned to designate the aforementioned wordplay related to the etymological meaning of the name Isaac ("Sarah laughed" - Gen 18:10b-15). ${ }^{138}$ Thus, as many modern scholars believe, the oldest core of the independent Abrahamic tradition is found in Gen 18:1-10a. It constituted the hieros logos of the sanctuary in Mamre near Hebron. We do not know when this local sanctuary became associated with Abraham. However, the already mentioned alleged parallelism between Gen 18:1-15 and Gen ${ }^{139}$ 32:23-33 may suggest that in both cases they could be written by the same author from the Babylonian exile. ${ }^{140}$ In fact, both of the pericopes have only very general similarities (direct theophany and the human form of divine beings). The rest (style, goals) are radically different in both of them. The promise of a son or the number of

134 Israel Finkelstein and Thomas Römer acknowledge, however, such a possibility (the existence of some old tradition about the grave) with regard to Genesis 25:9 ("Comments," 4). Nadav Na'aman maintains a critical attitude towards such a possibility ("The Pre-Priestly," 174-175).

135 Van Seters, Abraham, 293-295.

136 Jericke, Abraham, 35-52, 234-235, 301.

137 Jericke, Abraham, 234-235, 301; Na'aman, “The Pre-Priestly," 175.

138 Cf. arguments for the secondary nature of this scene in: Schmid, Literaturgeschichte, 92.

139 E.J. Hamori, "When Gods were Men." The Embodied God in Biblical and Near Eastern Literature (BZAW 384; Berlin - New York: de Gruyter 2008) 5-25, 65-68, 96-101.

140 Na'aman, "The Pre-Priestly," 165-166. 
three guests in Gen 18 have no correspondence in Gen 32. ${ }^{141}$ The aforementioned number of the three divine visitors who came to a couple of advanced age and promised them a descendant has its counterparts in Greek and Roman mythology. ${ }^{142}$ However, as noted by Thomas Römer ${ }^{143}$ the very number "three" may have completely different sources here. Hebron is associated with the number three in many biblical texts. The three leaders of Hebron are mentioned several times (Num 13:22; Josh 15:14; Judg 1:10; see also Gen 14:13-14). Their names were not explained. ${ }^{144}$ They are shown as Anak's descendants. Elsewhere, the Anakites are described as ancient, mythical inhabitants of the Hebron area (Num 13:22.28), and they are shown to have descended from giants (Num 13:33; cf. Gen 6:4; later also Deut 9:2). Therefore, it is possible that originally it was about three deified ancestors connected with Hebron, whom the author of Gen 18:1-15 wanted to "Yahwize" and connect with in the Abrahamic tradition. Thomas Römer ${ }^{145}$ names it "the policy of integrating non-Yahwist traditions into in the Abrahamic tradition." He considers such a translation to be best suited to the already observed "liberal" atmosphere (German: "liberale" Flair) in Gen 13; 18-19*. It fits well into the situation in the 7th century. Abraham in this original version is not yet portrayed as the ancestor of Judah, but an indigenous figure with whom various groups scattered throughout the Hebron region and its outskirts could identify. With regard to their neighbours from the East, the authors of this story follow the principle of a peaceful and friendly neighbourhood. ${ }^{146} \mathrm{~A}$ clear threat to this friendly atmosphere comes from the city, an example of which is primarily Sodom. Therefore, it is possible that the environment that generated this first literary version of the Abrahamic tradition had rural character and it was important for him to emphasize the importance of hospitality and offspring. ${ }^{147}$

The patriarch's subsequent connections and the expansion of the tradition associated with him resulted from the changes taking place in the story. The already mentioned connection of Abraham with the figure of Isaac and the identification of the promised patriarch descendant with the latter could have been the first one (Gen $13: 2.18 ; 18 * ; 21: 2) .{ }^{148}$ Some researchers even claim that as a result many

141 Römer, "Die politsche," 223.

142 T. Römer, "The Hebrew Bible and Greek Philosophy and Mythology: Some Case Studies," Sem 57 (2015) 193-196.

143 Römer, "Die politische," 223-224.

144 Perhaps they are Hurrian; cf. H. Seebass, Numeri. Kapitel 10,11-22,1 (BKAT 4/2; NeukirchenVluyn: Neukirchener Verlag 2003) 108.

145 Römer, "Die politische," 224.

146 Cf. Römer, "Die politische," 225.

147 Römer, "Die politische," 225.

148 See Konrad Schmid (Literaturgeschichte, 92-93) with the indication of certain doubts arising from the article by Detlef Jericke ("Die Geburt Isaaks - Genesis 21:1-8," Bibliche Notizen 88 [1997] 31-37). 
themes were transferred from Isaac to Abraham (cf. the mirror image in the arrangement of scenes in Gen 26, being at the same time more laconic in relation to the Abraham cycle). ${ }^{149}$ Nevertheless, the Abraham-Isaac storyline blends well in such an original mini-cycle with the storyline of Lot and his two sons: Ben-Ammi and Moab. (Gen 19:30-38). The cycle shaped in such a way explains the ethnic relations between the inhabitants of Judah (Isaac; cf. Amos 7:9.16) and the people of Moab, as well as the Ammonites, reflecting the political realities of the late monarchy age. ${ }^{150}$ Imparting such a new, "political-theological" aura to the story of Abraham-Lot (Gen 13*+18*-19+21*), allows us to believe that it could have been planned from the beginning so as to have a socio-political character (political theology ${ }^{151}$ ) and not exclusively a family one. In the above-mentioned, probable core of the entire Abrahamic tradition (Gen 18:1-10a), one can already find some kind of theological justification for the dynastic aspirations of a king residing in nearby Hebron, before this tradition was transferred to Abraham. ${ }^{152}$ The noticeable lack of such royal connotations in the Abrahamic tradition, as we have already mentioned, can be explained after Konrad Schmid by the fact that the Abrahamic tradition was cultivated not in the court circles, but within the community of landed nobility.

\subsubsection{The Purported Beginning of the Oldest Part of the Cycle in Genesis 12}

We have got used to seeing Abraham as a traveller on his way to the Promised Land and guided by God. Was he portrayed this way right from the beginning? Rather not. ${ }^{153}$ Let us look at Gen 12:6-9 first. The journey of Abraham described here (Shechem, Bethel) is in fact an inverted itinerary of Jacob's journey. ${ }^{154}$ Thus, we are dealing here with an adaptation of the old Israeli tradition to the needs of the new, Judean context. Generally, this is one of the motifs with the help of which Abrahamic tradition was combined with the tradition of Jacob. The mention of Shechem is here an explicit allusion to Gen 33:18-20 (cf. Gen 23). This place also anticipates the end of the Hexateuch - the speech of Joshua and the covenant

149 Lemański, Księga Rodzaju, 638-639.

150 E. Stern, Archeology of the Land of the Bible. II. The Assyrian, Babylonian, and Persian Periods 732-332 BCE (New York: Yale University Press 2001) 236-267.

151 Schmid, Literaturgeschichte, 93.

152 Schmid, Literaturgeschichte, 93.

153 Cf. Lipschits - Römer - Gonzalez, "The Pre-Priestly," 271-273.

154 Perhaps, in the original version, this journey did not even have a specific goal (vv. 6a.8a), which appeared only with the additions made by P (a view held by Lothar Ruppert). Most scholars, however, suggest these poems are of the exile or even post-exile origin. Therefore, this assumption is rather isolated; cf. discussion in: Lemański, Księga Rodzaju, 102-104. 
in Shechem (cf. Josh 24:1). ${ }^{155}$ Two conclusions can be drawn from the location of Abraham's camp between Bethel and Ai and the construction of an altar there (not at Bethel!). Either the Bethel sanctuary no longer functioned, or the author of the Bible declared it illegal. ${ }^{156}$

The journey itself then presupposes God's earlier words to Abraham (Gen 12:1-4a). This passage, in turn, clearly interrupts the priestly version of the beginning of the Abraham cycle (Gen 11:27-32; 12:4b-5), hence it can be considered a post-P composition, ${ }^{157}$ although some researchers classify it as post-Deuteronomist, and some (Lothar Ruppert) even find elements of an older tradition in it (above-mentioned 1a.2a*b.3b.4a together with the aforementioned 6a.8a). ${ }^{158}$ However, this passage, together with Gen 22, constitutes a clear internal inclusion within the cycle (cf. Gen 12:1 and 22:1). ${ }^{159}$ Since Chapter 22 - as mentioned previously - is to be classified as post-P, the same applies to the related program speech of the entire cycle, which is to be found in Gen 12:1-4a. Going further, it is even a program text for the entire patriarchal tradition with the prospect of linking it to the tradition of the exodus (cf. Deut 26:6). The bridge, a part of which is in Gen 12:2, leads first not to Exodus 1 (connection with the tradition of the exodus), but to Gen 46:1-5a, where we find a repetition of the "a great nation" motif (cf. also Gen 26:2.24). Summing up, we can say that Gen 12:1-4a.6-9 do not constitute the original beginning of the oldest version of the Abrahamic cycle. Both passages are considered by most scholars today to be the outcome of the editors' later works from the period of (post-P) post-Babylonian exile. However, it does not definitely exclude the opinion that this fragment (at least part of it) may be pre-P or close to P. ${ }^{160}$

\subsubsection{Gen 13:5-13 as the Actual Beginning of the Abraham-Lot-Sodom Narrative}

The combination of the traditions of Abraham, Sarah, and their descendant with Israel's neighbours, especially the Moabites and Ammonites (via Lot), in some way defines the identity of the people of Judah, who probably considered themselves heirs of the name "Israel" at that time (after 722 BC). It also regulates their relations with neighbouring nations. On the one hand, the inhabitants of

155 D. Kühn, "Abraham in Sichem (Gen 12,6-7). Die Pentateuch als theologisches Gemeinschaftprojekt im entstehenden Judentum 1," TQ 1 (2019) 19-33.

156 Römer, "Die politische," 215.

157 J.-L. Ska, "The Call of Abraham and Israel's Birth-certificate (Gen 12,1-4a)," J.-L. Ska, The Exegesis of the Pentateuch (FAT 66; Tübingen: Mohr Sebeck 2009) 46-66.

158 For discussions on this subject, cf. Lemański, Ksiegga Rodzaju, 102-104

159 Cf. U. Cassuto, A Commentary on the Book of Genesis. II. From Noah to Abraham (Jerusalem: Magnes Press 1984) 310; Carr, Reading the Fractures, 197-198.

160 Köckert, "Gen 20-22,” 173; Römer, "Die politische,” 215. 
Judea must have had a sense of ethnic ties with their neighbours, and on the other hand the awareness of being a separate political and social entity. The relations with the Arameans (via Nahor, Laban), the Arabs (via Ishmael and Keturah) and the Edomites (via Jacob and Esau) will be later described in the same manner. The lack of such ethnic ties, however, will be emphasised in the relations between Israel/Judah (Abraham) with the Philistines (the king and the inhabitants of Gerar; Gen 20) and the Egyptians (12:10-20; 16; 21: Hagar).

However, there initially existed a simple, primary Abraham-Lot cycle before further branches were introduced with the aim to organise the ethnic, political, and religious relations between Abraham (Judah) and his neighbours. At the first stage, Gen 18 and Gen 19 were interconnected. Only over time both chapters were preceded by a preparation in Gen $12^{*}$, and previously probably also by that in Gen 13*. ${ }^{161}$ Herman Gunkel believed that the original introduction to this primary mini-cycle is to be found in Abraham-Lot Sagenkranz, ${ }^{162}$ i.e. in the memory of the common ethnic roots and the subsequent dispersal of the descendants of both ancestors. ${ }^{163}$ It cannot be excluded that the original beginning was indeed either lost or replaced with a new exposure (Gen 13:5-13?). In either case, we are unable to reconstruct it.

After all the "younger" parts of the cycle have been distinguished, Gen 13:18-19* remain at our disposal. These chapters form a relatively coherent literary composition, the content of which was not yet known to priestly authors. In either case, we cannot include Gen 12:1-4a (The Call) and 12:6-9 (an itinerary modelled on the tradition of Jacob) - as it already has been mentioned - in this primary composition. The secondary verses from Gen 13:1-4 do not constitute such primary introduction either, as they clearly form a continu$u m$ with regard to Gen 12:10-20. ${ }^{164}$ The theme of promises does not belong to the primary version either (Gen 13:14-17). After all, it has broader connotations that go beyond the framework of the Abraham narrative - Lot (13:14 is in fact a concrete announcement from Gen 12:1b: "the land that I will show you"; in Gen 13:15 the promise concerns Abraham and his progeny for the first time; in Gen 12:7; $15: 18$ only his offspring; 13:16 develops the promises from Gen 12:2: great, countless nation and the great name). In other words, it is about broadening the horizon of events and references in relation to the thematic threads and circumstances of Gen 13:5-13; 18-19. Thomas Römer wants to include to the original version of Gen 13 the aforementioned 2.5.7-11a*.12b-13 (14a, 17). 18a. ${ }^{165} \mathrm{He}$ is aware, however, that there are differences in details when it comes to the clas-

161 Mühling, Blickt, 42.

162 H. Gunkel, Genesis, 3 ed. (HKAT 1/1; Göttingen: Vandenhoeck \& Ruprecht 1910); 9 ed. (1977) 159.

163 Lemański, Księga Rodzaju, 144.

164 For a discussion cf. Mühling, Blickt, 44, n. 91.

165 Römer, "Die politische," 220. 
sifications of particular poems (R.G. Kratz, E. Blum). These doubts apply to the above-mentioned 2,18a, but also to the aforementioned $6.11 \mathrm{~b} .12(=\mathrm{P})^{166}$ or to the above-mentioned $1.3-4.7 \mathrm{~b} .14-17.18 \mathrm{~b}=$ post-P). ${ }^{167}$ This does not mean, however, that this version originally and from the very beginning of the composition of Gen 18-19 was connected with it. In the present version, Gen 18:1b admittedly refers to Gen 13:18b, however, in the latter case, verse 18a seems to be secondary and focused on a closer and more distant context. ${ }^{168}$ What is more, in the pericope framework from Gen 13, numerous references to Gen 19 can be easily found (cf. Gen 13:10.12.13). For these reasons, many researchers looked for an older saga or a story in the background of Gen 13. Nevertheless, the text of this chapter leaves the impression that its author was already fully aware of the existence of Gen 18-19 and of the aforementioned relationships.

Attention should be certainly paid to the background of Gen 13, where a peaceful atmosphere in the relations between the group from Hebron, the capital of the mountain region in the southeast of Judea, and its neighbours living on the other side of the Jordan and the Dead Sea, can be found. This approach was created in the spirit of later Deuteronomist editors (cf. Deut 2:9.19), distinct from the prophetic and aggressive utterances towards the Moabites and the Ammonites (Isa 15-16; 25:10; Jer 48; Amos 2:10-11), or those from some psalms (Ps 83:6-9). ${ }^{169}$ These later Deuteronomist editors, however, seem to radicalise the statements from Gen 13, and emphasise that the lands on the east bank of the Jordan constitute a gift from Yhwh to these peoples. At the same time, however, they prefer to universalise tendencies (cf. Gen 14), which are not yet to be found in Gen 13. It is therefore difficult to determine exactly what historical context lies in the background of this chapter. The aforementioned Nadav $\mathrm{Na}$ ' $a m a n{ }^{170}$ suggests an "all-Israel" understanding of the figure of Abraham as well as the assumption that during the Judean monarchy, Moabites and Ammonites were not yet neighbours of Judah. This explains in fact the still friendly approach to these peoples. Still, can the conquest of Judah by Babylonians, when these peoples became neighbours to the inhabitants of Judah, constitute a terminus post quem in the dating of this text? ${ }^{171}$ Not necessarily. Thomas Römer ${ }^{172}$ poses here a legitimate question, why exactly this "post-exile" period combined with the historical background proper to Gen 13 should be correct, since neither Moab nor Ammon existed then as independent kingdoms? Römer points to the 8th or 7th century

\footnotetext{
166 Unlike Blum, Die Komposition, 285.

167 Kratz, Die Komposition, 276.

168 Blum, Die Komposition, 274.

169 Römer, "Die politische," $221+$ n. 56 (with references to literature).

170 Na'aman, "The Pre-Priestly," 161-162.

171 Such view was already held by Detlef Jericke (Abraham, 232).

172 Römer, "Die politische," 222.
} 
$\mathrm{BC}$ and at the same time poses question being rather rhetorical and speculative, according to him: “... is a 'rural' revolt against Josiah's expansionist policy visible here?"173

The dispute itself over pastures in Gen 13 is thematically connected with the dispute over the wells described in Gen 21:22-34 (Abraham and Abimelech) and Gen 26:12-22 (Isaac and Abimelech). However, it is difficult to determine how close these relationships are and their precedence over the other two versions. ${ }^{174}$ All things considered; it may boil down to a theme being rather popular in antiquity. Moreover, there exists a possibility of relating the Abraham-Lot dispute to the older Jacob-Laban dispute. In this case, Abraham would have played a much better role against his "brother" 175 Lot than Laban would have played against Jacob. Even if Gen 13:7 will be later shown to be the potential beginning of the original version (wjhj), such a separate and independent pericope would lack the punchline without Gen 18-19. ${ }^{176}$ The description of the land chosen by Lot as the "garden of God" (Gen 13:10) is clearly aimed at contrasting the "present appearance" and the effects of the events described in Gen 19. Therefore, we can agree with those researchers who regard Gen $13^{*}$ as the text which already assumes the events and locations of individual characters described in Gen 18-19. ${ }^{177}$ As a consequence, today the presence of the independent narrative is not sought and it is treated only as a kind of exposition (a shepherd's dispute) to the events described in Gen 18-19. ${ }^{178}$ Perhaps even the very motive of separation described in this chapter constitutes a political polemic directed against the Ammonites and Moabites $^{179}$ (cf. Deut 23:4; similarly as in Gen 19:30-38). The transformation of Lot from a shepherd (Gen 13:5) and a tent dweller (Gen 13:12) - a half-nomad, into a resident of the city who owns his house there (Gen 19:2) can serve the same purpose. Gen 12:10-20 also has similar polemical overtones later on, but this text - as already mentioned - is independent of the Abraham-Lot tradition and probably dates back to a later period.

173 Römer, "Die politische," 222.

174 We can naturally distinguish here the motif of a peaceful separation between the parties alone as the basic version (Gen 13:2*.5*.7a.8-10a.11a.18a*); for example Köckert, Vättergott, 250-255. This, however, does not change the fact that it is difficult to prove later that it has its origin Sitz im Leben in Gen 13.

175 The word "brother" (Gen 13:8) may have a purely rhetorical or a broader meaning. However, it cannot be ruled out that Lot, who is already Abraham's "nephew" in P (Gen 11:27.31; 12:5), was originally considered to be literally the patriarch's brother.

176 Römer, "Isaac (Patriarch) I," 260-266. Mühling, Blickt, 43, n. 85.

177 See Gunkel, Genesis, 176; Levin, Der Jahwist, 144.

178 G. von Rad, Das erste Buch Mose. Genesis, 10 ed. (ATD 2/4; Göttingen: Vandenhoeck \& Ruprecht 1976) 132; Van Seters, Abraham, 221-222; Blum, Die Komposition, 284.

179 G. Hepner, "The Separation Between Abram and Lot Reflects the Deuteronomic Law Prohibiting Ammonites and Moabites," ZAW 117 (2005) 36-52. 


\section{Subsequent Changes to the Image of Abraham}

Excluding Abraham's dialogue with God about the latter's righteousness (Gen 18:17-19.22b-32), which was placed between Gen 18 and Gen 19, we can point to the original version of the Abraham-Lot story in Gen 13:5-13; 18:1-10a.16; 19*. It seems similar to the Jacob-Laban story, which, for its part, may constitute the oldest core of the Jacob cycle and at the same time mark the tradition about the ancestor of the Israelites living in the north. ${ }^{180}$ The time when the two traditions (Jacob-Laban and Abraham-Lot) could be juxtaposed is probably the period after the fall of Samaria (722 BC), which is difficult to date precisely. It was then that the pre-exile local tradition of Abraham-Lot became able to begin penetrating the motives and elements of the tradition about Jacob (perhaps via Isaac). Following the findings of historians (Nadav $\mathrm{Na}$ 'aman), it is possible to conclude that the Abraham-Lot-Sodom story itself originated at the earliest towards the end of the monarchy in Judah, that is, when direct contacts between its inhabitants and those of ancient Moab and Ammon were possible.

In this segregated, original version of the Abraham-Lot story we have clearly some first stage of ethnogenesis present, important for the inhabitants of Judea, or at least its south-eastern part. This ethnogenesis was later expanded by subsequent accounts (Hagar, Keturah, Ishmael, Isaac). Nevertheless, it seems fair to say that at the beginning of the creation of the Abraham cycle, some far-reaching promises were still missing from it: blessing, land and numerous offspring. The patriarch was promised only one descendant, without a precise description, let alone a name. The extension of the scope of the promises was probably due to connections with the Jacob tradition and was often even inspired by it (e.g. the aforementioned itinerary in Gen 12:4-8*; the change of name in Gen 17:5). ${ }^{181}$ However, an important point must be noted here. In its original form, the Abraham-Lot story seems to show the patriarch as an indigenous local. Subsequent expansions (Gen 11:27-32; 12:1; 15:7) already make him clearly a wanderer or even a pilgrim who had come from Ur/Haran ${ }^{182}$ to Canaan at the express command of God and with specific promises (numerous offspring and land, blessing).

180 See Blum, Die Komposition, 202-203.

181 Carr, Reading the Fractures, 214.

182 The stay of Terah with his family in Haran is unjustified (cf. Gen 11:31b.32; 12:4b.5). The mention of Ur of the Chaldeans (Gen 11:28.31) - the name has applied since the time of Nabopolassar (626-605 BC) - the founder of the Chaldean dynasty - may be secondary and related to the need to justify the return meant for the deportees, the Jewish diaspora residing in this region. However, the presence in Harran may be the result of the role that this place plays (Laban lives here) in the tradition of Jacob (Gen 27:43; 29:4); see Blum, Die Komposition, 164-167; 343-344. Nevertheless, shortly after his exile, Abraham was identified with Haran 
This stage in the evolution of the Abrahamic tradition was clearly related to the needs arising from the political situation. The elites from Judea were in exile in Babylonia. The exile itself was not some cruel enslavement. The exiles enjoyed full civil liberties. Many of them made considerable fortunes there and achieved stability in life. Most of them, except from the enthusiasts - mainly from the priestly elite - had no desire or intention to return to the poor province which Judea, depopulated and economically devastated at that time, was. It was to them that the Abrahamic tradition, read in a new way, had to be addressed. In the first place, it had to bring hope. Just as God had once called their forefather from Ur of the Chaldeans and brought him to the Promised Land, so now he wants to lead them (back) to that land (cf. the motif of the "new Exodus" in Deutero-Isaiah). An encouragement of this kind was to be both an appeal to those who were reluctant and a strengthening for those enthusiasts who had already taken the step. ${ }^{183}$ It undoubtedly served to strengthen in them the awareness of their roots and their origins. Abraham, through his response to the call of God, i.e. his exodus from Mesopotamia and his journey towards the Promised Land, was for the so-called gôla - a community experiencing the trauma of exile a reference point for the construction of its own identity. The original message of this tradition (the Abraham-Lot cycle), which already emphasised this separate identity in a limited way (for the time being only in relation to the Moabites and Ammonites), was also important for them. ${ }^{184}$

Jean-Loius Ska is right in writing: ${ }^{185}$ "It is not difficult to see that this portrait of Abraham takes on more than one of the characteristics of 'gôlâ.' The principles Abraham followed were something close to the group returning from exile and eventually settling in Jerusalem. It is probable that at an early stage this group referred to the exodus as the 'founding myth' to validate their claims. Then, due to opposition from the 'people of the land,' the 'gôlâ' reinterpreted the figure of Abraham, making him the first 'pilgrim' to come from Mesopotamia, a journey that heralded a return from exile. In this way, the 'gôlâ' deprived its opponents of an important argument. Abraham was more of the father of those who returned

(Neh. 9:7). Already in the distant antiquity this place constituted an important commercial and stop-over center for numerous caravans; cf. D. Jericke, Die Ortsangaben im Buch Genesis. Ein historische-topographischer und literarisch-topographischer Kommentar (FRLANT 248; Göttinen: Vandenhoeck \& Ruprecht 2013) 87-88. On the term "(Ur) of the Chaldeans" (ibidem, 83-85)

183 Cf. J. Lemański, “'Poślij ludzi, aby zbadali kraj Kanaan...' (Num 13:1a). Kto i po co wprowadził tradycję o zwiadowcach wysłanych przez Mojżesza do Kanaanu?," Dla dobra Jego Ciała, którym jest Kościót (Kol 1:24). Księga Pamiątkowa Księdza Profesora Antoniego Paciorka (ed. G.M. Baran) (Częstochowa: Święty Paweł 2019) 223-246, esp. 238-242.

184 Mühling, Blickt, 46.

185 J.-L. Ska, "Essay on the Nature and Meaning of the Abraham Cycle (Gen 11,29-25,11)," J.-L. Ska, The Exegesis of the Pentateuch (FAT 66; Tübingen: Mohr Sebeck 2009) 43. 
from exile than of those who always remained in the homeland" (cf. Ezek 33:24 $\rightarrow$ Is $51: 1-2) .{ }^{186}$

\section{Conclusions}

The analysis carried out above allows us to draw some important conclusions regarding the origins of the Abrahamic tradition.

a) At the beginning of the Babylonian exile, Abraham was a figure regarded as the ancestor of the inhabitants of Judea (Ezek 32:24). Perhaps only its eastern part. The most likely initial version of the Abrahamic tradition is Gen 18:1-10a. The story of God visiting man, welcoming him and obtaining in return the promise of a descendant (not yet identified with Isaac) may have been an autonomous tradition associated with the local sanctuary (hieros logos) at Mamre, near Hebron. Whether it was associated with Abram (probably the original name of the patriarch) from the beginning, or whether it was used later in the creation of the Abraham-Lot cycle, is difficult to resolve. Its dating is a similar matter. The legend of the destruction of Sodom was rather certainly an autonomous tradition originally.

b) The first version of the cycle about Abr(ah)ama is connected with the Abraham-Lot story. It begins today with Gen 13:5-13 (the dispute and parting) and develops with the events described in Gen 18:1-10a.16;19*). It is difficult to decide conclusively whether Gen 13:5-13 originated immediately with Gen 18:1-10a.16; 19* or whether it has been added as part of the expansion of this mini-cycle. This introduction, in any case, has no self-narrated features which exist independently from Gen 18-19. This is because the previous version explicitly assumes the events described in Gen $18 *-19 *$. It is also probable that $\mathrm{Abr}(\mathrm{ah}) \mathrm{am}$ was presented in this original version as an indigenous person, not yet related to Lot (the kinship motif was developed by the P version). The main themes of this original cycle were: land, hospitality and descendant. Its purpose was to express a friendly attitude towards its neighbours from the East. Perhaps, then, only the purported extensions (Gen 13:19-30-38) were also intended to demonstrate the important differences between the descendants of Abr(ah)am (civilization, high standard of social attitudes) and the descendants of Lot (anti-civilization - negative behaviour and wrong choice in Gen 13:5-13, ambiguous attitude in Gen 19). This version of the story may have been written at the earliest at the end of seventh century. In addition to the local hieros logos of Mamre, another logical tradition about the destruc-

186 On both texts, among others, Mühling, Blickt, 84-94; Lemański, Księga Rodzaju, 64-67. 
tion of Sodom and Gomorrah was used in the construction of this first version. At first, the local character of the original Abrahamic tradition may have been related to the lack of its acceptance at the religious centre in Jerusalem, which was also the case for many other traditions (local cults and places like Mamre were considered unorthodox).

c) The extension identifying Isaac as the promised descendant is secondary. It can be connected with the development of the Abraham cycle and linking it with the Jacob cycle. It is very probably that the Abraham-Isaac connection predated the Abraham-Jacob connection. It can be assumed that this is the result of the events related to the Babylonian exile and the elevation of Abraham to the role of the ancestor of all Judea inhabitants (not only the area of Hebron). In turn, the motif of the patriarchs' tomb in Machpelah (near Hebron) was probably an attempt to desacralize the worship site in Mamre, not necessarily based on the actual tradition of the patriarch's tomb in this place.

d) The most important change compared to the original version is also related to the exile period. At the beginning (Ezek 33:24), the Abrahamic tradition served to justify the land claims of the inhabitants who remained in Judea. At this stage, it was not the descendant but the land that represented the most important topic of this tradition. Then there is also a polemic with the Egyptian diaspora (Gen 12:10-20) and other neighbouring communities (Gen 16). Moreover, the new experience made it possible to change the name of the patriarch and thus broaden the horizon of international connections (Gen 17:5 = P). As a consequence, it led to the expansion of ethnic relations (Lot - as a nephew; Ishmael - as a son; Keturah's offspring $=\mathrm{P} /$ post-P). However, most importantly, Abraham, an indigenous local and patriarch turned into a newcomer, a wanderer arriving from Ur of the Chaldeans, who trustfully followed God and His promises. The land was no longer taken into possession but was promised.

\section{Bibliography}

Albertz, R., Die Exilzeit. 6. Jahrhundert v. Chr. (Biblische Enzyklopädie 7; Stuttgart - Berlin - Köln: Kohlhammer 2001).

Alt, A., "Die Landname der Israeliten in Palästina," A. Alt, Kleine Schriften zur Geschichte des Volkes Israel (München: Beck 1953) I, 89-125.

Alter, R., "Sodom as Nexus: The Web of Design in Biblical Narrative," The Book and the Text. The Bible and Literary Theory (ed. R. Schwartz) (London: Blackwell 1990) 146-160.

Anbar, M. - Na'aman N., "An Account Tablet of Sheep from Ancient Hebron," Tel Aviv 13-14 (1986-1987) 3-12, https://www.academia.edu/12932470 [access: 3.10.2020].

Blenkinsopp, J., Abraham. The Story of a Life (Grand Rapids, MI - Cambridge: Eerdmans 2015). 
Bloch-Smith, E., "Israelite Ethnicity in Iron I: Archaeology Preserves What Is Remembered and What Is Forgotten in Israel's History," Journal of Biblical Literature 122 (2003) 401-425.

Bloch-Smith, E. - Nakhai, B.A., "A Landscape Comes to Life: The Iron Age I," Near Eastern Archaeology 62 (1999) 62-127.

Blum, E., Die Komposition der Vätergeschichte (Wissenschaftliche Monographien zum Alten und Neuen Testament 57; Neukirchen-Vluyn: Neukirchener Verlag 1984).

Blum, E., Studien zur Komposition des Pentateuch (Beiheft zur Zeitschrift für die alttestamentliche Wissenschaft 189; Berlin: de Gruyter 1990).

Blum, E., "Abraham I," Religion in Geschichte und Gegenwart, 4 ed. (ed. H.D. Betz) (Tübingen: Mohr Siebeck 1998) I, 70-74 (=RGG).

Blum, E., "Hosea 12 und die Pentateuchüberlieferungen," Die Erzväter in der biblischen Tradition. Festschrift für Matthias Köckert (eds. A. Hagedorn - H. Pfeiffer) (Beihefte zur Zeitschrift für die alttestamentliche Wissenschaft 400; Berlin: de Gruyter 2009) 291-321.

Bos, J.M., Reconsidering the Date and Provenance of the Book of Hosea. The Case for Persian-Period Yehud (New York: Bloomsbury - Clark 2013).

Bright, J., Historia Izraela (trans. J. Radożycki) (Warszawa: Pax 1994).

Caquot, A., "L'alliance avec Abram (Genèse 15)," Semitica 12 (1962) 51-66.

Carr, D.M., Reading the Fractures of Genesis. Historical and Literary Approaches (Louisville, KY: Westminster John Knox 1996).

Cassuto, U., A Commentary on the Book of Genesis. II. From Noah to Abraham (Jerusalem: Magnes Press 1984).

Coats, G.W., Genesis with an Introduction to Narrative Literature (Forms of Old Testament Literature 1; Grand Rapids, MI: Eerdmans 1983).

Cotter, D.W., Genesis (Berit Olam. Studies in Hebrew Narrative \& Poetry; Collegeville, MN: Liturgical Press 2003).

Dever, W.G., Who Where the Early Israelites and Where Did They Come From? (Grand Rapids, MI: Eerdmans 2003).

Dijkstra, M., "Ishmael," Dictionary of Deities and Demons in the Bible, ed. 2 (eds. K. van der Toorn - B. Becking - P.W. van der Horst) (Leiden - Boston, MA - Köln: Brill - Cambridge: Eerdmans 1999) 450-452 (=DDD).

Dozeman, T.B., "The Wilderness and Salvation History in the Hagar Story," Journal of Biblical Literature 117 (1998) 23-43.

Dozeman, T.B., The Pentateuch. Introducing the Torah (Minneapolis, MN: Fortress 2017).

Eichler, B.L, "Tabliczki z Mari," Stownik wiedzy biblijnej (eds. B.M. Metzger - M.D. Coogan) (Warszawa: Vocatio 1997) 754.

Eichler, B.L., “Tabliczki z Nuzi,” Słownik wiedzy biblijnej (eds. B.M. Metzger - M.D. Coogan) (Warszawa: Vocatio 1997) 754-755.

Eph'al, I., “Ismael' and Arab(s)': A Transformation of Ethnological Terms," Journal of Near Eastern Studies 35 (1976) 225-235.

Eph'al, I., The Ancient Arabs. Nomads an the Borders of the Fertile Crescent 9th-5th Centuries BC (Jerusalem: Magnes Press - Leiden: Brill 1982).

Faust, A., - Bunimovitz, S., "The Four Room Hause: Emboding Iron Age Israelite Society," Near Eastern Archaeology 66 (2003) 22-31. 
Faust, A., Israel's Ethnogenesis. Settlement, Interaction, Expansion and Resistance (London Oakville, CT: Equinox 2006).

Finkelstein, I., The Archaeology of the Israelite Settlement (Jerusalem: Israel Exploration Society 1988). Finkelstein, I., "The Rise of Early Israel. Archaeology and Long-Term History," The Origin of Early Israel - Current Debate: Biblical, Historical and Archaeological Perspectives (eds. S. AhituvE.D. Orens) (Beer Sheva 12; Beer Sheva: Ben Gurion University of the Negev 1996) 7-37.

Finkelstein, I., "The Rise of Jerusalem and Judah: the Missing Link," Levant 33 (2001) 105-115.

Finkelstein, I. - Römer, T., "Comments on the Historical Background of the Abraham Narratives. Between 'Realia,' and 'Exegetica,'” Hebrew Bible and Ancient Israel 3 (2014) 3-23.

Fischer, I., Die Erzeltern Israels. Feministisch-theologische Studien zu Genesis 12-36 (Beihefte zur Zeitschrift für die alttestamentliche Wissenschaft 222; Berlin - New York: de Gruyter 1994).

Fischer, I., "Möglichkeiten und Grenzen historisch-kritischer Exegese. Die «Opferung» der beiden Söhne Abrahams: Gen 21 und 22 im Kontext," Streit am Tisch des Wortes? Zur Deutung und Bedeutung des Alten Testaments und seiner Verwendung in der Liturgie (ed. A. Franz) (Pietas Liturgica 8; St. Ottilien: EOS 1997) 17-35.

Frevel, C., Geschichte Israels, 2 ed. (Stuttgart: Kohlhammer 2018).

Fritz, V., Archeologia biblijna (Mały Słownik; Warszawa: Verbinum 1995).

Gertz, J.C., "Abraham, Mose und der Exodus. Beobachtungen zur Redaktionsgeschichte von Genesis 15," Abschied vom Jahwisten. Die Komposition des Hexateuch in der jüngsten Diskussion (eds. J.C. Gertz - K. Schmid - M. Witte) (Beihefte zur Zeitschrift für die alttestamentliche Wissenschaft 315; Berlin - New York: de Gruyter 2002) 63-81.

Gibson, S., "Agricultural Terrace and Settlement Expansion in the Highlands of Early Iron Age Palestine. Is There Any Correlation Between the Two?," Studies in the Archaeology of the Iron Age Israel and Jordan (ed. A. Mazar) (Journal for the Study of the Old Testament Supplement Series 331; Sheffield: Sheffield Academic Press 2001) 113-146.

Glissmann, V., "Genesis 14: A Diaspora Novella?," Journal for the Study of the Old Testament 34 (2009) 34-45.

Golinets, V., "Die Gefährdung der Ahnfrau. Anmerkungen zu literarischen Abhängigkeiten in den Versionen von Genesis 12; 20; 26," Nächstenliebe und Gottesfurcht. Beiträge aus alttestamentlicher, semitistischer und altorientalistischer Wissenschaft für Hans-Peter Mathys zum 65. Geburtstag (eds. H. Jenni - M. Saur) (Alter Orient und Altes Testament 439; Münster: Ugarit-Verlag 2016) 91-114.

Grabbe, L.L., Ancient Israel. What Do We Know And How Do We Know It New York (London: Continuum 2007; reprint 2009).

Gunkel, H., Genesis, 3 ed. (Handkommentar Zum Alten Testament 1/1; Göttingen: Vandenhoeck \& Ruprecht 1910); 9 ed. (1977).

Hamori, E.J., "When Gods were Men." The Embodied God in Biblical and Near Eastern Literature (Beihefte zur Zeitschrift für die alttestamentliche Wissenschaft 384; Berlin - New York: de Gruyter 2008).

Hendel, R., "Politics and Poetics in the Ancestral Narratives," The Politics of the Ancestors (eds. M.G. Brett - J. Wöhrle) (Forschungen zum Alten Testament 124; Tübingen: Mohr Siebeck 2018) 11-34.

Hepner, G., "The Separation Between Abram and Lot Reflects the Deuteronomic Law Prohibiting Ammonites and Moabites," Zeitschrift für die alttestamentliche Wissenschaft 117 (2005) 36-52. 
Herzog, Z. - Singer-Avit, L., "Redefining the Center: The Emergence of State in Judah," Tel Aviv 31 (2004) 209-244.

Hesse, B. - Wapnish, P., "Can Pig Remains Be Used for Ethnic Diagnosis in the Ancient Near East?," The Archaeology of Israel. Constructing the Past. Interpreting the Present (eds. N.A. Silbermann - D.B. Small) (Journal for the Study of the Old Testament Supplement Series 237; Sheffield: JSOT Press 1997) 238-270.

Jericke, D., "Die Geburt Isaaks - Gen 21,1-8," Bibliche Notizen 88 (1997) 31-38.

Jericke, D., Abraham in Mamre. Historische und exegetische Studien zur Region von Hebron und zu Genesis 11,27-19,38 (Culture and History of the Ancient Near East 17; Leiden - Boston, MA: Brill 2003).

Jericke, D., Die Ortsangaben im Buch Genesis. Ein historische-topographischer und literarisch-topographischer Kommentar (Forschungen zur Religion und Literatur des Alten und Neuen Testaments 248; Göttinen: Vandenhoeck \& Ruprecht 2013).

Killebrew, A.E., Biblical Peoples and Ethnicity. An Archaeological Study of Egyptians, Canaanites, Philistines, and Early Israel 1300-1000 B.C.E. (Society of Biblical Literature Archaeology and Biblical Studies 9; Atlanta, GA: Society of Biblical Literature 2005).

Killebrew, A.E, "The Emergence of Ancient Israel: The Social Boundaries of a 'Mixed Multitude' in Canaan," "I Will Speak the Riddles of Ancient Times." Archaeological and Historical Studies in Honor of Amihai Mazar on the Occasion of His Sixtieth Birthday (eds. A.M. Maeir - P. de Miroschedji) (Winona Lake, IN: Eisenbrauns 2006) 555-572.

Knauf, E.A., Ismael. Untersuchungen zur Geschichte Palästinas und Nordarabiens im 1. Jahrtausend v. Chr (Abhandlungen des Deutschen Palästina-Vereins; Wiesbaden: Harassowitz 1985); 2 ed. (1989).

Knauf, E.A., "Hagar," The Anchor Bible Dictionary (ed. D.N. Freedman) (New York: Doubleday 1992) III, 18-19 (=ABD).

Knauf, E.A. "Ishmael (Son of Abraham and Hagar) I: Hebrew Bible/Old Testament," Encyclopedia of the Bible and Its Reception (eds. C.M. Furey et al.) (Berlin - Boston, MA: de Gruyter 2016) XIII, 352-355 (=EBR).

Kochavi, M., "Khirbet Rabûd = Debir," Tel Aviv 1 (1974) 2-33.

Köckert, M., Vätergott und Väterverheissungen. Eine Auseinandersetzung mit Albrecht Alt und seinen Erben (Forschungen zur Religion und Literatur des Alten und Neuen Testaments 142; Göttingen: Vandenhoeck \& Ruprecht 1988).

Köckert, M., "Die Geschichte der Abrahamüberlieferung," Congress Volume Leiden 2004 (Supplements to Vetus Testamentum 109; Leiden - Boston, MA: Brill 2006) 103-128.

Köckert, M., "Wie wurden Abraham- und Jakobüberlieferung zu einen 'Vätergeschichte' verbunden?," Hebrew Bible and Ancient Israel 3 (2014) 43-66.

Köckert, M., "Gen 20-22 als nach-priestliche Erweiterung der Vätergeschichte," The Post-Priestly Pentateuch (eds. F. Giuntoli - K. Schmid) (Forschungen zum Alten Testament 101; Tübingen: Mohr Siebeck 2015) 157-176.

Köckert, M., “Gottes 'Bund' mit Abraham und die 'Erwählung Israels in Genesis 17,'” Covenant and Election in Exilic and Post-Exilic Judaism (ed. N. MacDonald) (Studies of the Sofia Kovalevskaja Research Group on Early Jewish Monteism 5; Forschungen zum Alten Testament 2/79; Tübingen: Mohr Siebeck 2015) 1-28. 
Köckert, M., "Hagar und Ismael. Politische Aspekte im Wandel der Überlieferungen," The Politics of the Ancestors (eds. M.G. Brett - J. Wöhrle) (Forschungen zum Alten Testament 124; Tübingen: Mohr Siebeck 2018) 233-258.

Kratz, R.G., Die Komposition der erzählenden Bücher des Alten Testament (UTB 2157; Göttingen: Vandenhoeck \& Ruprecht 2000).

Kratz, R., "The Pentateuch in Current Research: Consensus and Debate," The Pentateuch (eds. T.B. Dozeman - K. Schmid - B.J. Schwartz) (Forschungen zum Alten Testament 78; Tübingen: Mohr Siebeck 2011) 31-61.

Kühn, D., "Abraham in Sichem (Gen 12,6-7). Die Pentateuch als theologisches Gemeinschaftprojekt im entstehenden Judentum 1," Theologische Quartalschrift 1 (2019) 19-33, DOI: 10.14623/ thq.2019.1.19-33.

Lemaire, A., "Cycle primitif d'Abraham et contexte géographico-politique," History and Traditions of Early Israel. Studies Presented to Eduard Nielsen (eds. A. Lemaire - B. Otzen) (Supplements to Vetus Testamentum 50; Leiden: Brill 1993) 62-75.

Lemański, J., "W poszukiwaniu tradycji o Izaaku," Colloquia Theologica Ottoniana 2 (2013) 63-76.

Lemański, J., Księga Rodzaju. Rozdziały 11,27-36,43. Wstęp - przektad z oryginatu - komentarz (Nowy Komentarz Biblijny. Stary Testament 1/2; Częstochowa: Edycja Świętego Pawła 2014).

Lemański, J., “Zakaz spożywania wieprzowiny (Kpł 11,7; Pwt 14,8): Czas i przyczyny jego sformułowania," Warszawskie Studia Teologiczne 28/1 (2015) 79-102.

Lemański, J., "Hagar - Matka niewybranych?,” „Niewiastę dzielna kto znajdzie?” (Prz 31,10). Rola kobiet w biblijnej historii zbawienia (eds. A. Kubiś - K. Napora) (Lublin: Wydawnictwo KUL 2016) 29-51.

Lemański, J., “Abraham versus Jakub,” Collectanea Theologica 88/4 (2018) 35-51.

Lemański, J., “'Poślij ludzi, aby zbadali kraj Kanaan...' (Lb 13,1a). Kto i po co wprowadził tradycję o zwiadowcach wysłanych przez Mojżesza do Kanaanu?," Dla dobra Jego Ciała, którym jest Kościót (Kol 1,24). Księga Pamiątkowa Księdza Profesora Antoniego Paciorka (ed. G.M. Baran) (Częstochowa: Święty Paweł 2019) 223-246.

Lemański, J., "Kim był Abraham i skąd pochodził? Kilka uwag na temat potencjalnych śladów tradycji o Abrahamie," The Biblical Annals 10/1 (2020) 5-30.

Levin, C., Der Jahwist (Forschungen zur Religion und Literatur des Alten und Neuen Testaments 157; Göttingen: Vandenhoeck \& Ruprecht 1993).

Levin, C., "Jahwe und Abraham im Dialog: Genesis 15," Gott und Mensch im Dialog. Festschrift für Otto Kaiser zum 80. Geburtstag (ed. M. Witte) (Beihefte zur Zeitschrift für die alttestamentliche Wissenschaft 345; Berlin - New York: de Gruyter 2004) 237-257.

Lipschits, O., "The Rural Economy of Judah during the Persian Period and the Settlement History of the District System," The Economy of Ancient Judah in Its Historical Context (eds. M.L. Miller, - E. Ben Zvi, - G.N. Knoppers) (Winona Lake, IN: Eisenbrauns 2015) 237-264.

Lipschits, O., "Abraham zwischen Mamre und Jerusalem," The Politics of the Ancestors (eds. M.G. Brett - J. Wöhrle) (Forschungen zum Alten Testament 124; Tübingen: Mohr Siebeck 2018) 187-209.

Lipschits, O. - Römer, T. - Gonzalez, H., "The Pre-Priestly Abraham Narratives from Monarchic to Persian Times," Semitica 59 (2017) 261-296.

Machinist, P.B., “Ebla,” Encyklopedia biblijna (ed. P.J. Achtemeier) (Warszawa: Vocatio 1999) 233-236. 
Mowinckel, S., “"Rahelstämme' und 'Leastämme'," Von Ugarit nach Qumran. Beiträge zur alttestamentlischen und altorientalischen Forschung. Festschrift O. Eissfeldt (eds. J. Hempel - L. Rost) (Beihefte zur Zeitschrift für die alttestamentliche Wissenschaft 77; Berlin; de Gruyter 1958) $129-150$.

Mühling, A., "Blickt auf Abraham, euren Vater". Abraham als Identifikationsfigur des Judentums in der Zeit des Exils und des Zweiten Tempels (Göttingen: Vandenhoeck \& Ruprecht 2011).

Na'aman, N., "The Kingdom of Judah under Josiah,” Tel Aviv 18 (1991) 3-71.

Na'aman, N., "Canaanite Jerusalem and Its Central Hill Country Neighbours in the Second Millenium B.C.E.," Ugarit-Forschungen 24 (1992) 275-291.

Na'ama, N., "Four Notes on the Size of Late Bronze Canaan", Bulletin of the Amerciab Schools of Oriental Research 313 (1999) 31-37.

Na'aman, N., "David's Sojourn in Keilah in the Light of the Amarna Letters," Vetus Testamentum 60 (2010) 87-97.

Na'aman, N., "The Kingdom of Judah in the 9th Century BCE: Text Analysis versus Archaeological Research," Tel Aviv 40 (2013) 247-276.

Na'aman, N., "The Pre-Priestly Abraham Story as a Unified Exilic Work," Scandinavian Journal of the Old Testament 29/2 (2015) 157-181.

Na'aman, N., "Memories of Canaan in the Old Testament," Ugarit-Forschungen 47 (2016) 129-146.

Nihan, C., "Abraham Traditions and Cult Politics in the Persian Period. Moriyyāh and Šalem in Genesis," The Politics of the Ancestors (eds. M.G. Brett - J. Wöhrle) (Forschungen zum Alten Testament 124; Tübingen: Mohr Siebeck 2018) 259-281.

Niemann, H.M., "Juda und Jerusalem. Überlegungen zum Verhältnis von Stamm und Stadt und zur Rolle Jerusalems in Juda,” Ugarit-Forschungen 47 (2016) 147-190, https://www.academia. edu/30682756 [access: 3.10.2020].

Ofer, A., "Hebron," The Encyclopedia of Archaeological Excavations in the Holy Land (ed. E. Stern) (New York et al.: Simon \& Schuster 1993) II, 606-609.

Ofer, A., "All the Hill Country of Judah: From a Settlement Fringe to a Prosperous Monarchy," From Nomadism to Monarchy. Archaeological and Historical Aspects of Early Israel (eds. I. Finkelstein - N. Na'aman) (Jerusalem: Israel Exploration Society 1994) 92-121.

Pikor, W., Rola ziemi w przymierzu Boga z Izraelem. Studium historyczno-teologiczne Ksiegi Ezechiela (Lublin: Wydawnictwo KUL 2013). English edition: The Land of Israel in the Book of Ezekiel (Library of Hebrew Bible/Old Testament Studies 667; London: Bloomsbury Clark 2018). de Pury, A., "Abraham. The Priestly Writer's 'Ecumenical' Ancestor," Rethinking the Foundations. Historiography in the Ancient World and in the Bible. Essays in Honour of John Van Seters (eds. T. Römer - S.L. McKenzie) (Beihefte zur Zeitschrift für die alttestamentliche Wissenschaft 294; Berlin - New York: de Gruyter 2000) 163-181.

de Pury, A., "Pg as the Absolute Beginning," Les dernières rédactions du Pentateuque, de l'Hexateuque et de l'Ennéateuque (eds. T. Römer - K. Schmid) (Bibliotheca Ephemeridum Theologicarum Lovaniensium 203; Leuven: Peeters 2007) 99-128.

de Pury, A., "The Jacob Story and the Beginning of the Formation of the Pentateuch," A Farewell to the Yahwist? The Composition of the Pentateuch in Recent European Interpretation (eds. T.B. Dozeman - K. Schmid) (Symposium Series 34; Atlanta: SBL 2006) 51-72.

de Pury, A., "Genèse 12-36," Introduction à l'Ancien Testament, 2 ed. (eds. T. Römer - J.-D. Macchi - C. Nihan) (Le Monde de la Bible 49; Genève: Labor et Fides 2009) 217-238. 
Raban, A., "Standardized Collared-Rim Pithoi and Short Lived Settlements," Studies in the Archaeology of Israel and Neighboring Lands in Memory of Douglas L. Esse (eds. W.S.R. Wolff) (Atlanta, GA: ASOR 2001) 493-518.

von Rad, G., Das erste Buch Mose. Genesis, 10 ed. (Das Alte Testament deutsch 2/4; Göttingen: Vandenhoeck \& Ruprecht 1976).

Rainey, A.F., "Who Is a Canaanite? A Review of the Textual Evidence," Bulletin of the Amerciab Schools of Oriental Research 304 (1996) 1-15.

Rainey, A.F., The El-Amarna Correspondence (Handbuch der Orientalistik 110/1-2; Leiden Boston, MA: Brill 2015) I-II.

Römer, T., "Isaac et Ismaël. Concurrents ou cohéritiers de la promesse? Une lecture de Genèse 16," Études Théologiques et Religieuses 74 (1999) 161-172.

Römer, T., "Recherches actuelles sur le cycle d'Abraham," Studies in the Book of Genesis. Literature, Redaction and History (ed. A. Wénin) (Bibliotheca Ephemeridum Theologicarum Lovaniensium 155; Leuven: Peters 2001) 179-211.

Römer, T., "Exodusmotive und Exoduspolemik in den Erzvätererzählungen," Berührungspunkte. Studien zur Sozial- und Religionsgeschichte Israels und seiner Umwelt. Festschrift für Rainer Albertz zu seinem 65. Geburtstag (eds. I. Kottsieper - R. Schmitt - J. Wöhrle) (Alter Orient und Altes Testament 350; Münster: Ugarit-Verlag 2008) 3-19.

Römer, T., "Abraham and the Law and the Prophets," The Reception and Remembrance of Abraham (eds. P. Carstens - N.P. Lemche) (Perspectives on Hebrew Scriptures and Its Contexts 13; Piscataway, NJ: Gorgias 2011) 103-118.

Römer, T., "Abraham Traditions in the Hebrew Bible outside the Book of Genesis," The Book of Genesis. Composition, Reception, and Interpretation (eds. C.A. Evans - J.N. Lohr - D.L. Petersen) (Supplements to Vetus Testamentum 152; Leiden - Boston, MA: Brill 2012) 159-180.

Römer, T., "Lot, l'hospitalité et l'inceste," Tabou et transgressions. Actes du colloque organisé par le Collège de France, Paris, les 11-12 avril 2012 (ed. J.M. Durant) (Orbis Biblicus et Orientalis 247; Fribourg - Göttingen: Vandenhoeck \& Ruprecht 2015) 135-144.

Römer, T., "The Hebrew Bible and Greek Philosophy and Mythology: Some Case Studies," Semitica 57 (2015) 185-203.

Römer, T., "Isaac (Patriarch) I. Hebrew Bible/Old Testament," Encyclopedia of the Bible and Its Reception (eds. C.M. Furey et al.) (Berlin - Boston, MA: de Gruyter 2016) XIII, 260-266 (=EBR).

Römer, T., "Beschneidung in der Hebräischen Bibel und ihre literarische Begründung in Genesis 17," Dem Körper eingeschrieben. Verkörperung zwischen Leiberleben und kulturellem Sinn (eds. M. Jung - M. Bauks - A. Ackermann) (Studien zur Interdisziplinären Anthropologie; Wiesbaden: Springer 2016) 227-241.

Römer, T., "Die politische Funktion der vorpriesterlichen Abrahamtexte," The Politics of the Ancestors (eds. M.G. Brett - J. Wöhrle) (Forschungen zum Alten Testament 124; Tübingen: Mohr Siebeck 2018) 211-232.

Rofé, A., "The Admonitions not to Leave the Promised Land in Genesis 24 and 26 and the Authorization in Genesis 46," The Post-Priestly Pentateuch (eds. F. Giuntoli-K. Schmid) (Forschungen zum Alten Testament 101; Tübingen: Mohr Siebeck 2015) 177-184.

Rudnik-Zelt, S., Hoseastudien. Redaktionskritische Untersuchungen zur Genese des Hoseabuches (Forschungen zur Religion und Literatur des Alten und Neuen Testaments 213; Göttingen: Vandenhoeck \& Ruprecht 2006). 
Ruppert, L., Genesis. Ein kritischer und theologischer Kommentar. III. Gen 25,19-36,43 (Forschung zur Bibel 106; Würzburg: Echter 2005).

Sapir-Hen Lidar, "Food, Pork Consumption, and Identity in Ancient Israel," Near Eastern Archaeology 82 (2019) 52-59.

Schmid, K., Erzväter und Exodus Untersuchungen zur doppelten Begründung der Ursprünge Israels innerhalb der Geschichtsbücher des Alten Testaments (Wissenschaftliche Monographien zum Alten und Neuen Testament 81; Neukirchen-Vluyn: Neukirchener Verlag 1999).

Schmid, K., Literaturgeschichte des Alten Testaments. Eine Einführung (Darmstadt: Wissenschaftliche Buchgeselschaft 2008), 2 ed. (2014).

Schmid, L., "Die Darstellung Isaaks in Genesis 26,1-33 und ihr Verhältnis zu den Parallelen in den Abrahamerzählungen," Gesammelte Aufsätze zum Pentateuch (ed. L. Schmid) (Beihefte zur Zeitschrift für die alttestamentliche Wissenschaft 263; Berlin: de Gruyter 1998) 167-223.

Seebass, H., Numeri. Kapitel 10,11-22,1 (Biblischer Kommentar, Altes Testament 4/2; NeukirchenVluyn: Neukirchener Verlag 2003).

Sergi, O., "Judah's Expansion in Historical Context,” Tel Aviv 40 (2013) 226-246.

Ska, J.-L., "The Call of Abraham and Israel's Birth-certificate (Gen 12,1-4a)," J.-L. Ska, The Exegesis of the Pentateuch (Forschungen zum Alten Testament 66; Tübingen: Mohr Sebeck 2009) 46-66.

Ska, J.-L., "Essay on the Nature and Meaning of the Abraham Cycle (Gen 11,29-25,11)," J.-L. Ska, The Exegesis of the Pentateuch (Forschungen zum Alten Testament 66; Tübingen: Mohr Sebeck 2009) 23-45.

Soggin, J.A., "Abraham and the Eastern Kings: on Genesis 14," Solving Riddles and Untying Knots. Biblical Epigraphic, and Semitic Studies in Honor of Jonas C. Greenfield (eds. Z. Zevit S. Gitin - M. Sokoloff) (Winona Lake, IN: Eisenbrauns 1995) 283-291.

Sparks, K.L., "Israel and the Nomads of Ancient Palestine," Community Identity in Judean Historiography. Biblical and Comparative Perspective (eds. G.N. Knoppers - K.A. Riston) (Winona Lake, IN: Eisenbrauns 2009) 9-26, https://www.academia.edu/1059818 [access: 4.09.2020].

Stern, E., Archaeology of the Land of the Bible. II. The Assyrian, Babylonian, and Persian Periods 732-332 BCE (New York: Yale University Press 2001) 236-267.

Tarasiuk, M., Starożytny Izrael. Historiograficzne implikacje w rozwoju i upadku zjednoczonej monarchii (Kraków: Enigma 2010).

Van Seters, J., Abraham in History and Tradition (New Haven, CT - London: Yale University Press 1975).

Van Seters, J., Prologue to History. The Yahwist as Historian in Genesis (Louisville, KY: Westminster John Knox 1992).

de Vaux, R., Histoire ancienne d'Israel. Des origines à l'installation en Canaan (Etudes bibliques; Paris: Gabalda 1971).

Wöhrle, J., "The Integrative Function of the Law of Circumcision," The Foreigner and the Law. Perspectives from the Hebrew Bible and the Ancient Near East (eds. R. Achenbach R. Albertz - J. Wöhrle) (Beihefte zur Zeitschrift für altorientalische und biblische Rechtsgeschichte 16; Wiesbaden: Harrassowitz 2011) 71-87.

Wöhrle, J., "Abraham und das Leben im Ausland. Zur Intention der Ahnfrau-Erzählung in Gen 12,10-20 und ihrer frühen inner- und ausserbiblischen Rezeption," Biblische Notizen 151 (2011) 23-46. 
Wöhrle, J., Fremdlinge im eigenen Land. Zur Entstehung und Intention der priesterlichen Passagen der Vätergeschichte (Forschungen zur Religion und Literatur des Alten und Neuen Testaments 246; Göttingen: Vandenhoeck \& Ruprecht 2012).

Wöhrle, J., "Jacob, Moses, Levi. Pentateuchal Figures in the Book of the Twelve," The Formation of the Pentateuch (eds. J.C. Gertz et al.) (Forschungen zum Alten Testament 111; Tübingen: Mohr Siebec 2016) 997-1014.

Wöhrle, J., “'Gebt mir einen Grabbesitz bei euch'. Zur Entstehung und Intention der Erzählung von Abrahams Grabkauf in Genesis 23," Eigensinn und Entstehung der Hebräischen Bibel (eds. J.J. Krause - W. Oswald - K. Weingart) (Forschungen zum Alten Testament 136; Tübingen: Mohr Siebeck 2020) 63-76;

Wagner, A., Genesis 14. Its Literary Growth, Its Messages, and Historical Context (MA Thesis; Tel Aviv University 2014).

Westermann, C., Genesis. II. Genesis 12-36 (Biblischer Kommentar 1/2; Neukirchen-Vluyn: Neukirchener Verlag 1981).

Zadok, R., "On Early Arabians in the Fertile Crescent," Tel Aviv 17 (1990) 223-231.

Ziemer, B., Abram-Abraham. Kompositionsgeschichtliche Untersuchungen zu Genesis 14, 15 und 17 (Beihefte zur Zeitschrift für die alttestamentliche Wissenschaft 350; Berlin - New York: de Gruyter 2005).

Zobel, H.J., "Beiträge zur Geschichte Gross-Judas in früh- und vordawidischer Zeit," Congress Volume Edinburg 1974 (Supplements to Vetus Testamentum 28; Leiden: [s.n.] 1975) 253-277. 